medRxiv preprint doi: https://doi.org/10.1101/2022.01.13.22269234; this version posted January $17,2022$. The copyright holder for this preprint (which was not certified by peer review) is the author/funder, who has granted medRxiv a license to display the preprint in It is made available under a CC-BY-NC-ND 4.0 International license.

\title{
Increased airborne transmission of COVID-19 with new variants. Implications for health policies.
}

B.R. Rowe $e^{a}$, A. Canosa $a^{b}$, A. Meslem ${ }^{c}$ and F. Rowe

${ }^{a}$ Rowe Consulting, 22 chemin des moines, 22750 Saint Jacut de la Mer (France).

${ }^{b}$ CNRS, IPR (Institut de Physique de Rennes)-UMR 6251, Université de Rennes, 35000 Rennes, (France).

'University of Rennes, LGCGM, 3 Rue du Clos Courtel, BP 90422, 35704, Rennes, CEDEX 7, France

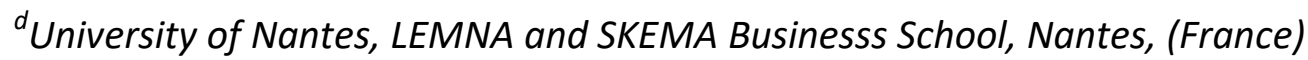

\section{$\underline{\text { Abstract }}$}

The aim of the present paper is to highlight that new variants, either of higher viral load such as delta or higher contagiousness like omicron, lead to an even higher airborne transmission than historical strains. We first review the question of the route of contamination and of the dose following exposure, and the importance of the counting unit for pathogens, itself linked to the dose-response law. Using the counting unit of Wells, i.e. the quantum of contagium, we develop the conservation equation of quanta which allows deriving the value of the quantum concentration at steady state for a well-mixed room. With the choice of an exponential response function, this leads to the famous Wells-Riley equation. The analysis points out the importance of a number of parameters such as the time of exposure, the quantum production rate, mask wearing and the incidence rate in the population in order to evaluate the risk. The link with the monitoring concentration of carbon dioxide is made and used for a risk analysis of a variety of situations for which we have made concrete $\mathrm{CO}_{2}$ time monitoring. The main conclusion of these observations is that the present norms of ventilation, already insufficient, are not respected, especially in a variety of public premises, leading to high risk of contamination. Finally, we insist that public health policy in the field of airborne transmission should be based on a multi parameter analysis, considering the whole complexity of dose evaluation. 
medRxiv preprint doi: https://doi.org/10.1101/2022.01.13.22269234; this version posted January 17, 2022. The copyright holder for this preprint (which was not certified by peer review) is the author/funder, who has granted medRxiv a license to display the preprint in It is made available under a CC-BY-NC-ND 4.0 International license .

\section{I-Introduction}

Since its emergence at the end of 2019 in the city of Wuhan, province of Hubei in China the COVID-19 disease has spread throughout the world. The pandemic has been responsible for 5.3 million of deaths worldwide at the date of December $12^{\text {th }}, 2021$, and over 270 million of persons have been infected (JHU, 2021). A variety of public and health measures and recommendations have been decided in several countries to contain COVID-19 spreading. Recommendations pertain more to personal hygiene as, for example, washing hands, coughing in his elbow, and keeping a social distancing with other individuals. However, collective measures have been often more coercive. They include, amongst others, lockdown, closing of specific activities such as restaurant services, quarantine, sanitary pass and last but not least human surveillance data tracking. Although decided in order to mitigate the pandemic health consequences, these measures had profound side effects, sometimes deleterious, on the economy and population mental health (Carlin et al., 2021).

Developing a rational basis for prevention (epidemiology prevention) is absolutely necessary to avoid irrational measures such as interdiction of outdoor activity in under-crowded area or organizing a kind of carousel circulation in commercial centers. This requires identification of both causal mechanisms explaining the spread of the virus or disease and of the factors related to the occurrence of disease i.e. risk factors, whose presence or absence are likely to favor the spread of the virus in the population. A rational public health policy related to the disease also requires careful evaluation of the pharmaceutical and non-pharmaceutical interventions to reduce the extent of disease. This should be the key role of epidemiology (Kuller, 2016).

As described in a large number of publications and commonly admitted, there are three routes of transmission of respiratory diseases. The first can be considered as a person-to-person transmission, occurring via direct close contact, when microdroplets of physiological fluids emitted by an infected person (when sneezing, coughing or talking) are projected directly on the mucosa (lips, nose, eyes) of another person in a kind of ballistic way. The second one is linked to self-touches of the face mucosa by hands which have been contaminated, either in the first way, or by touching contaminated surfaces (fomites). The third route is due to the creation of a persistent aerosol of microdroplets in a range of size which prevents their rapid sedimentation on the floor. If this aerosol is emitted by an infected person, it can be re-breathed leading to further contamination. This route is known as "aerosol" or "airborne" transmission. Mainly due to historical reasons (Randall et al., 2021) it was outright denied by most of health authorities including WHO, or governmental agencies such as the CDC in the US (Center of Disease Control) or the HAS (Haute Autorité de Santé) in France. Then mitigation measures were mainly decided considering the first two ways of transmission: social distancing, washing hands etc. Unfortunately for public health, the consideration of airborne transmission should have led to a variety of other decisions, especially in the field of indoor air quality.

Ironically, everything was at hand for suspecting the importance of airborne transmission in the COVID-19 pandemic. As soon as the first half of the last century, Wells and his co-workers have led a large number of experiments and developed concepts still largely in use nowadays in the field of respiratory diseases. Wells has exposed his visionary views and summarized his work in a book of 1955 that any epidemiologist involved in this topic should have read (Wells, 1955). With his coworker Riley he developed the famous Wells-Riley model (Riley et al., 1978) which has been the basis of a lot of avatars and developments, especially in the last two decades (Rowe et al., 2021; Rudnick and Milton, 2003).

The non-consideration of airborne transmission has led L. Morawska, a leading scientist in the field of human emitted aerosols, to raise an alarm on its importance (Morawska and Cao, 2020), followed by a call co-signed by more than two hundred researchers of the field in the 
medRxiv preprint doi: https://doi.org/10.1101/2022.01.13.22269234; this version posted January 17, 2022. The copyright holder for this preprint (which was not certified by peer review) is the author/funder, who has granted medRxiv a license to display the preprint in It is made available under a CC-BY-NC-ND 4.0 International license.

mainstream press (New York Times, 2021). Nowadays the very importance of airborne transmission of the COVID-19 disease is largely recognized and the reader is referred to the review in Science (and references therein) of Wang et al (Wang et al., 2021a) which relates the whole story, leading to the conclusion that airborne transmission is the major route of its spreading. Complementary details can be found in (Greenhalgh et al., 2021; Tang et al., 2021).

Viruses mutate constantly, leading to new variants which can be more infectious than the previous strain. This must be considered in the epidemiology of the disease. The classification of variants is beyond the scope of the present paper and is rather complicated since there is not a single nomenclature. Their scientific name may refer to their lineage (a lineage is a group of closely related viruses with a common ancestor) and to mutations resulting from changes in the genetic code leading eventually to new variants (CDC, 2021). An expert group of WHO has recommended using letters of Greek alphabet to name variants in non-specialized audience (WHO, 2021a). Recently it has been shown that the $\delta$ variant (B.1.617.2), which appeared first in India in October 2020, leads to a much higher viral load in respiratory fluids than initial strains, referred hereafter as IS (Li et al., 2021a; Teyssou et al., 2021; von Wintersdorff et al., 2021). According to recent observations the new omicron variant, which is spreading very fast in a number of country, has a smaller viral load than the $\delta$ one but is nevertheless more contagious for microbiological reasons. In the framework of a WellsRiley or re-breathed air model and following the approach developed by Rowe et al. (Rowe et al., 2021) in their estimation of the relative risk in outdoor versus indoor transmission, we demonstrate in the present paper that an increased viral load in respiratory fluids will lead also to a much higher airborne transmission.

The present paper is not a review, and its scope is not to discuss in detail the problem of viral load linked to variants, but the implication of a higher viral load on airborne transmission. We shall first recall the basic notions that are used in airborne transmission of respiratory diseases. Then, we shall treat first the case of homogeneous transmission in indoor environment, essentially following the Wells-Riley approach. We pursue with the inhomogeneous case with emphasis on the close contact transmission. Applying the analytical formula, that can be used for risk assessment indoor needs to refer to some ventilation rates. Therefore, the norms prevailing in this field are presented and the relative risk for different variants (following viral load and microbiological characteristics), and various situations, calculated. In the course of this work, we have also performed measurements of $\mathrm{CO}_{2}$ concentrations in a variety of environments, which demonstrate that in the real-life ventilation is most often insufficient and that the homogeneous hypothesis is most often verified. We finish by emphasizing the implications for health policy of the increased airborne transmission, which is certainly the main transmission way for variants which result in high viral load. Following other authors (Vuorinen et al., 2020) we insist on the importance of the time of exposure although unfortunately most of the public policy is based on the distance of exposure, probably due to the initial denial of airborne transmission.

\section{II- basic notions in airborne transmission}

Humans emit numerous microdroplets from the mouth and nostrils, with a variety of characteristics which depend on the respiratory activity (Johnson et al., 2011; Morawska et al., 2009). Below a given size they can linger for a long time in the air and are then known as "aerosol" or "airborne" (Rowe et al., 2021). Contamination of a healthy person by an infected one occurs in the airborne way by inhalation of infected microdroplets exhaled by one or several infectors. 
medRxiv preprint doi: https://doi.org/10.1101/2022.01.13.22269234; this version posted January 17, 2022. The copyright holder for this preprint (which was not certified by peer review) is the author/funder, who has granted medRxiv a license to display the preprint in It is made available under a CC-BY-NC-ND 4.0 International license.

II-1. Infectious microdroplets, variants and viral load.

Microdroplets emitted by a human can be characterized by their size and composition, including viral load. Their sizes depend mainly on their origin from the respiratory tract and of their evolution in the ambient air, mainly by water evaporation. The largest droplets, that behave in a ballistic way, are most often emitted by talking, directly from the mouth and hence from saliva. The smallest ones come from various parts of the respiratory tract, including the lungs. They have a large distribution of sizes, and many are below $10 \mu \mathrm{m}$, especially after evaporation of some of the largest ones. In a kind of reversible way, the smallest ones $(<5 \mu \mathrm{m})$ can penetrate deep in the lung when rebreathed and, from this point of view, they are known as respirable aerosols (Brown et al., 2013; Wang et al., 2021a).

One of the most sophisticated apparatuses used for the size characterization of human emitted aerosols, is the specific wind tunnel developed by L. Morawska and her coworkers at the Queensland University of Technology, at Brisbane, in Australia. It uses a variety of sizing and diagnostic techniques (Johnson et al., 2011; Morawska et al., 2009) and their results show four main modes of distribution size around $0.8,1.8,3.5$, and $5.5 \mu \mathrm{m}$ respectively. By mode of distribution we mean a peak of the frequency distribution of size, which can be visualized as the highest peak seen in the distribution. If there is only one peak the distribution is monomodal, otherwise it is multimodal.

The viral load can be defined as a mean value of the number of viruses per unit volume of respiratory fluids, or also per particle of a given size. Let's remind that the respiratory fluids are composed mainly of water with components like mucus, proteins and viruses in low concentration (Vejerano and Marr, 2018). By particle we mean as well spherical microdroplets composed mainly of water than "dry nuclei" which are the result of water evaporation or any intermediate more or less hydrated. The viral load of infectious particles is of course a key parameter of their infective power, as will be discussed in section II-4. It has to be understood that, for the smallest particles, this mean value is statistical i.e. it implies a large distribution of particles with various viral content. The fact that the mean viral load per particle can be lower than unity implies that some microparticles will not contain any virus but does not imply that it will be the case of all particles, as assumed by some authors. Moreover, due to the very large number of these smallest particles, they can be very efficient in airborne transmission. As stated in the introduction, the viral load per unit volume of respiratory fluids depends on the viral strain (Li et al., 2021a; Teyssou et al., 2021). Note also that, due to evaporation, exhaled microdroplets can result in particles of lower size but higher viral load relative to their size.

\section{II-2. Host entry factors.}

In a series of remarkable experiments with rabbits and mice Wells (Wells, 1955) has demonstrated that, concerning aerosols, very fine particles (which include dry nuclei) have a much higher infectious power than coarse particle, at least for disease such as tuberculosis and influenza. Wells explanation was that human body has a very efficient system to prevent coarse particle larger than a few micrometers to penetrate deep in the respiratory system. Beside defenses against very coarse particles, specific to the upper respiratory tract (nostrils, nasal cavity, mouth, throat, pharynx), and voice box ( $\operatorname{larynx})$ ), mucociliary clearance is a primary innate defense mechanism of the lung (see the reviews by Bustamante-Marin and Ostrowski (Bustamante-Marin and Ostrowski, 2017) and Kuek (Kuek and Lee, 2020)) which helps to remove smaller particles and pathogens from the lower respiratory tract, using the epithelium formed by ciliated and secretory cells. These later 
medRxiv preprint doi: https://doi.org/10.1101/2022.01.13.22269234; this version posted January 17, 2022. The copyright holder for this preprint (which was not certified by peer review) is the author/funder, who has granted medRxiv a license to display the preprint in It is made available under a CC-BY-NC-ND 4.0 International license.

provide a mucus which is expelled by cilia toward the digestive system after swallowing. It is known that most respirable pathogens do not provoke illness when ingested, and there is currently no evidence that COVID-19 could be transmitted by ingestion (German Federal Institute for Risk Assessment, 2021). Note that the mechanism of very fine particles deposition into the lungs has been the subject of numerous studies for mineral toxic dusts, such as asbestos (Nurminen et al., 1999).

Nowadays, the formidable progress of microbiology allows studying the influence of cellular characteristics on the vulnerability of cells to coronaviruses, which start with binding of the viral spike (S) proteins to cellular receptors (Hoffmann et al., 2020). Following some data, it has been anticipated that infectivity was higher in the upper respiratory tract and that the nose was a primary target (Hou et al., 2020). However the severity of the COVID-19 is linked to the occurrence of pneumonia, followed by acute diffuse alveolar damage, which can be due to direct lung infection by airborne microparticles (Morawska and Cao, 2020; Wu and Zha, 2020) or by indirect infection from the oropharynx to the lung by aspiration of the viral inoculum when breathing (Hou et al., 2020). Also study of nonhuman primate model reveals, after autopsy, the importance of lung lesions in macaques (Rockx et al., 2020). It seems reasonable to assume that, when the virus reaches the lungs directly before some immunity able to inhibit viral reproduction has been acquired, it could result in devastating pneumonia, as sometimes reported in young, healthy subjects.

It has to be noticed that as well the remarkable experimental results of Wells for particle size than the most recent findings of microbiology cannot be directly used to develop a quantitative model of transmission risk. Therefore, some concepts and approaches must be developed prior to the establishment of any model.

\section{II-3. Concepts of dose and notion of quantum.}

As discussed in Rowe et al (Rowe et al., 2021) and others (Brouwer et al., 2017; Haas et al., 2014) the notions of level and dose of exposure are easily defined in the case of chemical or physical hazards (such as toxic gases or asbestos): in this case the level of exposure is the concentration of toxic and the dose the quantity inhaled, ingested etc. However, these definitions are much more difficult for biological pathogen agents that are not easy to measure and have the possibility to replicate in the target host (Haas et al., 2014; Pan et al., 2019). Concerning aerosols and as stated by Haas et al (Haas et al., 2014) "precise information on the concentration of pathogens in aerosols has a lot of uncertainty associated with it". Moreover and for any kind of disease (i.e. respiratory, digestive etc.), the effect of the dose could depend on the way of transmission: inoculation, ingestion, airborne etc. Having defined what a dose is, the work of epidemiology is to assess quantitatively what is the risk for a given dose: of course, by nature, such an assessment is statistical; it results most often in a law linking the probability of infection to the dose.

For example a dose can be defined as TCID50 (Tissue Culture Infection Dose) which is the quantity of pathogens which gives cytopathic effects in $50 \%$ of infected cells in a tissue culture (Yezli and Otter, 2011). Then, by infecting young healthy volunteers, it is possible to establish a correlation between TCID50 and the dose necessary to infect 50\% of humans known as HID50 (Yezli and Otter, 2011)). Of course, such studies are not ethically possible with humans for diseases that can have strong health consequences, including death.

For airborne transmission of respiratory diseases, the definition of a dose is far from being straightforward since measuring the concentration of pathogens in the air is extremely difficult (Haas et al., 2014). Therefore, Wells (Wells, 1955) defined the quantum of contagium as a hypothetical quantity that has been inhaled per susceptible individuals (men or animals) when $63.2 \%$ (corresponding to $1-\exp (-1)$ ) of these individuals display symptoms of infection. It is linked to a probability of infection which follows a Poisson law (see sub-section II-7). Contrary to what has been claimed in the literature (Sze To and Chao, 2010), the quantum has no dimension but is a counting 
medRxiv preprint doi: https://doi.org/10.1101/2022.01.13.22269234; this version posted January 17, 2022. The copyright holder for this preprint (which was not certified by peer review) is the author/funder, who has granted medRxiv a license to display the preprint in It is made available under a CC-BY-NC-ND 4.0 International license.

unit (like dozens versus unity, or moles compared to molecules) which is clearly linked to the chosen law for the probability of infection. Therefore, this quantity considers a variety of mechanisms: inhalation of airborne particles, pathogen inhibition by host defenses or losses by some other processes, before any replication will start in an infected cell. Obviously, this quantity corresponds statistically to a number of pathogens higher than one.

These statistical concepts do not mean that a number of pathogens higher than one is absolutely necessary to start infection in any given single case, as assumed by some authors. Indeed, the so-called "single hit" models which have been developed (Haas et al., 2014; Haas, 1983; Louten, 2016; Teunis and Havelaar, 2000; Zwart et al., 2009) considering a very small probability, although not zero, of infection by a single pathogen, make the link with statistical risk assessment. Further, and as stated by Haas et al. (Haas et al., 2014), the concept of Minimum Infective Dose is very misleading since "Minimum" suggests some threshold effect for the infection. Haas et al. emphasize that the term "minimal infectious dose" corresponds to the average dose administered and most frequently really relates to the average dose required to cause half of the subjects to experience a response; they suggest that the term "median infectious dose" should be more appropriate and they show that it is not possible to infer the probability of infection by a single pathogen from the magnitude of the median infectious dose.

It must be noticed that, in order to assess the relative risk between two situations of airborne contagion, considering the dose of rebreathed airborne particles (i.e. the inhaled flow rate of particles exhaled by other people) is enough as shown by Rowe et al (Rowe et al., 2021). Clearly this is also the way chosen in rebreathed air models (Rudnick and Milton, 2003) inducing $\mathrm{CO}_{2}$ monitoring of indoor space.

II-4. Expression of the quantum production rate and link with infectious aerosols.

To build a probabilistic model of infection it is necessary to know the production rate of quanta (as defined by Wells) by an infector. It is defined per unit time and per infector (unit: $\mathrm{h}^{-1}$ for example) and can be deduced from epidemiological observations (Gammaitoni and Nucci, 1997) but also linked to the distributions of microdroplets emitted by humans, together with the knowledge of viral load in respiratory fluids and of the mean number of viruses required to initiate infection.

Following Buonnano et al (Buonanno et al., 2020) the production rate of quanta $q$ can be written as:

$$
q=V L \times c \times p \times \int_{0}^{10 \mu m} N_{d}(D) \times d V_{d}(D)
$$

Where $V L$ is the viral load in the respiratory fluid, $c$ is a factor of proportionality between the viral content (copies/unit volume) and quanta, $p$ is the pulmonary exhaled volume rate (volume/unit time), $N_{d}(D)$ the size distribution of droplet concentration (diameter $D$ ) of volume $V_{d}$. The factor c depends on the microbiological characteristics of the variant and can explain a higher value of $q$ (and hence a higher contagiousness) even with a lower value of $V L$.

As mentioned earlier in section II-1, Morawska et al. (Morawska et al., 2009) have shown that microdroplets emitted by different expiratory activity correspond to four different modes centered on mid-point diameters respectively of $D_{1}=0.8, D_{2}=1.8, D_{3}=3.5$, and $D_{4}=5.5 \mu \mathrm{m}$. Their concentrations depend on the expiratory activity as shown in Table 1 adapted from table 1 of Buonanno et al. (Buonanno et al., 2020). 
medRxiv preprint doi: https://doi.org/10.1101/2022.01.13.22269234; this version posted January 17, 2022. The copyright holder for this preprint (which was not certified by peer review) is the author/funder, who has granted medRxiv a license to display the preprint in It is made available under a CC-BY-NC-ND 4.0 International license.

Table 1: Concentrations (in $\mathrm{cm}^{-3}$ ) of the microdroplets size modes during various expiratory activities

\begin{tabular}{lllll} 
& \multicolumn{4}{l}{ Centered mid-point diameter $(\mu \mathrm{m})$} \\
\cline { 2 - 5 } Expiratory activity & 0.80 & 1.8 & 3.5 & 5.5 \\
\hline Voiced counting & 0.236 & 0.068 & 0.007 & 0.011 \\
Whispered counting & 0.110 & 0.014 & 0.004 & 0.002 \\
Unmodulated vocalization & 0.751 & 0.139 & 0.139 & 0.059 \\
Breathing & 0.084 & 0.009 & 0.003 & 0.002 \\
\hline
\end{tabular}

For a given activity, It results that the general form of equation (1) can be simplified as:

$$
q_{j}=V L \times c \times p \times \sum_{i=1}^{i=4} N_{i j} \times V_{i}
$$

where the subscripts $i$ and $j$ refer respectively to the size mode and the expiratory activity.

From equation (2) and Table 1 it is clear that the production rate of quanta can vary widely depending on the expiratory activity but also on the virus strain through $V L$ and $c$. Note also that the level of activity (which implies a given metabolism) plays an important role on this rate (Buonanno et al., 2020). Therefore it can change with time for a given infector.

The most important point of this section is that the production rate of quanta can be considered as proportional to the viral load in the respiratory fluids and to a factor (c) which depends on the virus microbiological characteristics. Although the viral load depends probably on the particle origin from the respiratory tract, it is assumed throughout the present paper that an enhanced viral load corresponds in proportion to an enhanced quantum rate production of a given activity. This is a reasonable assumption since the quantum production rate is a statistical mean quantity that does not consider the diversity of particle emission process in various part of the respiratory tract. Note also that the quantum production rate is also just proportional to the volume of emitted microdroplets. If particles were mono sized it could be considered as proportional to the number of particles.

\section{II-5. Influence of the mask on the production rate of quanta}

Buonnano et al assume that the production rate of quanta is a sum of production rates corresponding respectively to the four modes mentioned in Table 1. From this, equation (2) can read:

$$
q=\sum_{i=1}^{i=4} q_{i}
$$

where for sake of simplicity we have omitted the subscript $j$ which refers to the activity. Therefore, with the mask it should be considered that the quantum production rate could be written:

$$
q^{\prime}=\sum_{i=1}^{i=4} \beta_{i} \times q_{i}
$$

Where $\beta_{i}$ correspond to the proportion of particles going through the mask and also directly outside, due to the leaking flows at the seal with the face. Besides this problem of leak, filtration efficiency changes considerably with particle size. For the smallest size, below $1 \mu \mathrm{m}(i=1)$, the surgical mask can be very inefficient as shown by (Chen and Willeke, 1992; Weber et al., 1993) leading to values close to 0.5 for the flow through the filtration media. However due to the importance of the leaks (Rengasamy et al., 2014), it could be assumed that $\beta_{i}$ is in fact independent of the size (which, of course, is not the case for very large particles which behave in a ballistic way). It must be noticed of 
medRxiv preprint doi: https://doi.org/10.1101/2022.01.13.22269234; this version posted January 17, 2022. The copyright holder for this preprint (which was not certified by peer review) is the author/funder, who has granted medRxiv a license to display the preprint in It is made available under a CC-BY-NC-ND 4.0 International license.

course that the mask, not only reduces the quantum production rate of infectors, but also in the same way the inhaled flow rate of particles per healthy susceptible.

\section{II-6. Dose calculation.}

At this stage we shall consider quanta of contagium only, although the same developments and definitions can apply to the number of infectious particles or viruses.

The dose of inhaled quanta can be expressed as the integral over time of exposure of the product of quantum concentration $n_{q}$ (quanta per unit volume) by the pulmonary volume inhalation rate $p$ (volume per unit time):

$$
X=\int_{0}^{t} n_{q} \times p \times d t
$$

Note that this definition of the dose does not require a homogeneous distribution of quanta in space. Only $n_{q}(\vec{r}, t)$ at the inhaled location (mouth and nostrils) has to be considered. Note also that due to the extremely low concentration of quanta in air, $n_{q}(\vec{r}, t)$ is not really a continuous function of $\vec{r}, t$ (since a number of viruses is of course an integer) but can be treated as such due to the statistical aspect of the problem (as discussed previously for the viral load of microdroplets).

The dose $X$ has no dimension but is dependent of the choice of the counting unit with its probability law.

II-7 Risk assessment: infection probability.

It is clear that the probability of infection must be a monotonically increasing function of the dose, starting from zero at dose zero and increasing toward an asymptote $P=1$ for large values of $X$. There are several probability laws that can be used (Brouwer et al., 2017; Haas et al., 2014) but quite often a Poisson law is employed:

$$
P=1-\exp (-X)
$$

For a small dose $X \ll 1$, this probability of transmission is just $X$. For any transmission law and as can be shown by a Taylor expansion, the probability is then proportional to $X$, considering that $P=0$ when the dose is zero.

\section{III- homogeneous model of transmission.}

In a homogeneous (well mixed) model, it is assumed that there is no spatial gradient of risk in a space where the infectors and the receivers either evolve or stay in place. In other words, it is assumed that the infectious microdroplets are evenly distributed. This is typical of two kinds of situations. It happens first instantly in a space where mechanical mixing ventilation is used and where ventilation airflow is supplied using particular terminal units designed to promote a high jet induction (i.e., vortex diffusers, lobed diffusers). This case lies to forced convection state. However when forced convection is small (case of poor ventilation for example) compared to the ones induced by other phenomena, such as natural convection, wake of moving people, door openings for letting people in or out, it can be shown that, in many situations, the well mixed room hypothesis is also valid (Bazant, 2020). Then, we consider an evenly distribution of microdroplets obtained by 
medRxiv preprint doi: https://doi.org/10.1101/2022.01.13.22269234; this version posted January $17,2022$. The copyright holder for this preprint (which was not certified by peer review) is the author/funder, who has granted medRxiv a license to display the preprint in It is made available under a CC-BY-NC-ND 4.0 International license.

induced turbulent flows, although this distribution is not really continuous due to its discrete character (very low concentration). Using $\mathrm{CO}_{2}$ as a proxy of infectious microdroplets (i.e. quanta), observations show that this condition is most often fulfilled (see section VII).

Of course, if others ventilations techniques are used (Su et al., 2022), the generated directional air flows within the room lead to preferential aerosols trajectories following air distribution patterns. This point is discussed in more details in section VIII-2.

\section{III-1. Conservation equations of quanta.}

In a homogeneous model it is possible to write a conservation equation for the concentration $n_{i}$ of mono-sized microdroplets in a volume $V$, as developed by Rowe et al (Rowe et al., 2021) for the relative risk assessment between outdoor and indoor situations. In the same way, an equation of conservation can be applied to the quanta of contagium as defined by Wells (Wells, 1955). Let $N_{q}$ be the total number of quanta in the volume $\mathrm{V}$, and $n_{q}$ the quantum concentration, considering the quantum production rate per infector $q$ (as defined in section II.4) and introducing a quantum lifetime, which can be considered as the virus lifetime $\tau_{i}$ this equation reads:

$$
\frac{d N_{q}}{d t}=V \times \frac{d n_{q}}{d t}=I \times q-q_{2} \times n_{q}-\frac{n_{q}}{\tau_{i}} \times V
$$

where $I$ is the number of infectors within the volume and $q_{2}$ is the ventilation rate or/and integrates other phenomena or processes as discussed in VIII-3.

The solution of which is:

$$
n_{q}(t)=n_{q}^{\infty} \times\left[1-\exp \left(-\frac{t}{\tau_{1}}\right)\right]
$$

with:

$$
\tau_{1}=V /\left(q_{2}+V / \tau_{i}\right)
$$

The concentration of quanta at stationary state i.e. $t \sim a$ few $\tau_{1}$ is:

$$
n_{q}^{\infty}=\frac{I \times q}{\left(q_{2}+\frac{V}{\tau_{i}}\right)}
$$

which, if the virus lifetime is neglected, reduces to:

$$
n_{q}^{\infty}=\frac{I \times q}{q_{2}}
$$

Note that if there is some air treatment (filtration or sterilization or both) for the volume $V$, it can be considered as an increase in the flow rate of fresh air and therefore results in an increase of $q_{2}$ value. Indeed, it is also possible to introduce the virus lifetime as an increase in the ventilation flow rate through equations ( 9 and 10 ). The virus lifetime $\tau_{i}$ depends on a variety of phenomena including UV irradiation.

In a situation where the stationary state has already been reached in a homogeneous volume at the beginning of exposure then, following equation (11 and 5), the inhaled dose is:

$$
X=\frac{I \times q \times p \times t}{q_{2}}
$$


medRxiv preprint doi: https://doi.org/10.1101/2022.01.13.22269234; this version posted January 17,2022 . The copyright holder for this preprint (which was not certified by peer review) is the author/funder, who has granted medRxiv a license to display the preprint in It is made available under a CC-BY-NC-ND 4.0 International license.

\section{III-2. Dose and risk.}

In the Wells-Riley model (Riley et al., 1978), it is assumed that the probability of transmission to one healthy person (susceptible) follows a Poisson law, which leads to:

$$
P=1-\exp \left(-\frac{I \times q \times p \times t}{q_{2}}\right)
$$

Note that equation (7) allows to consider any unsteady cases, including the case of very poorly ventilated room which can be considered as corresponding to $q_{2}<<V / t, t$ being the time of exposure. Then assuming that the quantum concentration is zero at $t=0$ (case of a tutorial room at the beginning of a lecture after a weekend for example) it is easy to show that the dose of exposure can now be approximated by:

$$
X=\frac{p \times I \times q \times t^{2}}{2 \times V}
$$

which is valid at $t<<\frac{V}{q_{2}}$ and can be used with any probability law including Poisson.

\section{IV- Inhomogeneous transmission.}

In many circumstances the well mixed model presented above is completely relevant to indoor situations, as shown by measurement of $\mathrm{CO}_{2}$ used as an indicator, or by order of magnitude calculations considering turbulent indoor flow velocity (with typical values around $0.1 \mathrm{~m} / \mathrm{s}$ ) induced by a variety of phenomena, including natural convection. However, there are undoubtedly conditions where substantial gradients of pathogens (quantum) prevail leading to a risk which is, amongst other parameters such as the time of exposure, dependent on the indoor position of infectors and susceptible persons. Two situations can be depicted for inhomogeneous transmission: the case of indoor viral transport on rather large distances, i.e., which are close to the space typical length and the event of close contact between an infector and a susceptible person.

\section{IV-1. Inhomogeneous transmission: indoor long range.}

Inhomogeneous infection patterns are reported for a number of well-documented transmission events in closed spaces, especially in restaurants (Liu et al., 2021; Kwon et al., 2020; Lu et al., 2020) but also in other places such as aircrafts (Toyokawa et al., 2022). Generally, in these specific well studied cases, inhomogeneity was created by the mechanical ventilation system of air conditioning (hereafter AC) with recirculation, inducing locally larger air velocity. One typical and largely mediatized event has been the subject of numerical modeling (Liu et al., 2021). Numerous published works in the field do not relate to a specific observed event but to hypothetical situations supposed to represent typical cases, such as a supermarket (Vuorinen et al., 2020). These models rely on CFD (Computational Fluid Dynamics) calculations of the air flow stream, using a variety of softwares, such as Open Foam for example. Then the micro-particle behavior is estimated using a variety of approach (Lagrangian, Monte-Carlo). Note that, for a Stokes number $<<1$, they are just assumed to follow the flow. The Stokes number can be defined as the ratio of two times $\tau_{a} / \tau_{h}, \tau_{a}$ being the characteristic time of velocity accommodation of a particle to the flow velocity and $\tau_{h}$ the hydrodynamic time (equal to a typical length of the problem divided by the flow velocity). Note that for most problems dealing with the behavior of exhaled aerosol particles in indoor situation the Stokes number remains much smaller than one. 
medRxiv preprint doi: https://doi.org/10.1101/2022.01.13.22269234; this version posted January 17, 2022. The copyright holder for this preprint (which was not certified by peer review) is the author/funder, who has granted medRxiv a license to display the preprint in It is made available under a CC-BY-NC-ND 4.0 International license .

II is also worthwhile to point out that long range modeling is applied to a specific geometry of the environment, as such it can be applied for the design of a new building for example but is limited for applications in the real life of most existing buildings and therefore, on the short term, for driving public policy.

\section{IV-2. Short range contact.}

It is now largely admitted that the transmission of COVID-19 disease by close contact is most often an airborne one, referred in the literature as "short-range airborne transmission" (Chen et al., 2020; Cortellessa et al., 2021). Close to the emitter the turbulent respiratory plume (or puff for cough and sneeze) can have a much higher quantum (viral) load than in the ambient air of the indoor space considered. Several models of this phenomena have been proposed, some very simple (Chen et al., 2020) others more sophisticated. The recent one by Cortellessa et al. (Cortellessa et al., 2021) employs CFD for the air flow and Lagrangian calculations for the particles to derive the dose and the risk as a function of the distance between infector and susceptible. Not only the distance but also the time of exposure is considered in order to assess the risk, but the time is limited to fifteen minutes. Also, large microdroplets which behave more or less in a ballistic way are considered and shown to prevail at very short distance $(<60 \mathrm{~cm})$, with a contribution to the dose being completely negligible at higher distances, demonstrating the airborne character of most airborne contamination in close contact, excepted intimate.

In their paper, Cortellessa et al. also made a comparison with the homogeneous risk. However, the comparison is restricted to the same time of exposure of fifteen minutes, with an initial concentration of quanta equal to zero. Therefore, it does not consider long times of exposure for the homogeneous case at steady state, as found for example in schools but such an extension can easily be done. Also the comparison should have to include the probability of close contact, which is not done. Such a close contact risk assessment is anyway extremely useful for public policy.

\section{$\underline{\text { V-Present norm of ventilation and air quality }}$}

Different ventilation techniques exist (Cao et al., 2014) and their role is to maintain hygienic conditions in occupant's indoor spaces. In most situations, the ventilation is general. In this case, the whole volume is treated by introducing indoors the fresh air taken outdoors, to dilute the contaminants in the occupied zone by mixing the introduced fresh air with foul air. Less widespread, are ventilation techniques not based on the principle of contaminant dilution. For example, displacement ventilation, which is another general ventilation technique more suitable for large polluted volumes, generates a stratification of the environment by natural convection using fresh air colder than the ambient air, introduced at low velocity near the floor. Personalized ventilation is a local ventilation technique that treats the microclimate around the occupant, who must be in a fixed position to benefit from introduced fresh air (for example in a workstation or theatre).

Focussing on public-access buildings, such as classrooms, restaurants, or supermarkets, where human density is high, the general ventilation employs either mechanical systems or is simply natural. Natural ventilation consists in airing with permanent voluntary leaks on the building envelop or with punctual manual opening of the windows. When mechanical ventilation is installed, the design of ventilation network uses total mandatory volumetric flow rates of fresh air to be introduced in the building. This total volumetric flow rate is calculated based on standards in force. In Table 2, these standards are recalled for some territories (France, Europe and USA). Ventilation flow rate could be expressed with one of three units $\left(\mathrm{m}^{3} / \mathrm{h}, \mathrm{l} / \mathrm{s}\right.$ or $\mathrm{ACH}$ the air changes per hour). In standards the unit air flow rate is given either per person (the so-called People Flow rate, PFR in 
medRxiv preprint doi: https://doi.org/10.1101/2022.01.13.22269234; this version posted January 17, 2022. The copyright holder for this preprint (which was not certified by peer review) is the author/funder, who has granted medRxiv a license to display the preprint in It is made available under a CC-BY-NC-ND 4.0 International license .

$\mathrm{L} / \mathrm{s} /$ pers. in Table 2) or per square meter of floor area (the so-called Area Flow Rate, AFR in $\mathrm{L} / \mathrm{s} / \mathrm{m}^{2}$ in Table 2). In the latter case, the default Occupancy Ratio (OR in $\mathrm{m}^{2} /$ pers. In Table 2 ) is needed to deduce the volumetric flow rate to be introduced in a specific space (in $\mathrm{L} / \mathrm{s}$ or $\mathrm{m}^{3} / \mathrm{h}$ ). Since the Occupancy ratio OR of a space is not always specified in the standards, a usage value is often considered.

It can be seen from Table 2 that unit ventilation flow rates do not vary significantly from one regulation to another. For classrooms, the common value is PFR $=5 \mathrm{~L} / \mathrm{s} /$ pers. (i.e., $18 \mathrm{~m}^{3} / \mathrm{h} /$ pers.), which allows to maintain $\mathrm{CO}_{2}$ concentration below the Threshold Concentration Value, TCV $=1300$ ppm (Table 2). In the USA standard (ASHRAE, 2003; ASHRAE, 2019), the cumulative value $\operatorname{PFR}[\mathrm{L} / \mathrm{s} / \text { pers. }]^{*}(\mathrm{~A} / \mathrm{OR})+\mathrm{AFR}\left[\mathrm{L} / \mathrm{s} / \mathrm{m}^{2}\right]^{*} \mathrm{~A}\left[\mathrm{~m}^{2}\right]$, where $A$ is the floor area, is defined as the flow rate in the Breathing Zone. As for the French standard (JORF, 1978), the differentiation made between children (children under 15 years old) and adults (or persons of 15 years old or more) in PFR definition $\left(15 \mathrm{~m}^{3} / \mathrm{h} /\right.$ child and $18 \mathrm{~m}^{3} / \mathrm{h} /$ adult) is not biologically relevant according to (Déoux, 2010) because children emit as much $\mathrm{CO}_{2}$ as adults. Children being more fragile than adults, the individual ventilation flow rate PFR should on the contrary be higher for them. The UE Regulation (CEN, 2019) recommends PFR $=10 \mathrm{~L} / \mathrm{s} /$ pers. for sensitive and fragile persons with special requirements, which should be the case for young pupil.

As discussed in the previous sections, aerosols are the main contamination routes of COVID-19 (Morawska et al., 2020; Morawska and Milton, 2020; Setti et al., 2020; Zhang et al., 2020a), and the exposure becomes critical indoors. It is now widely admitted that the ventilation is, beside the mask, the most effective way for reducing indoor airborne transmission (Morawska and Cao, 2020; Morawska et al., 2020; Wang et al., 2021b) in particular for highly insulated and airtight buildings, where the building envelop infiltration is reduced to a minimum to respect thermic regulation. The measure of Indoor $\mathrm{CO}_{2}$ concentration is considered in standards (see Table 2) as an indirect measure of indoor air quality (IAQ) or as a proxy of ventilation rate.

All the standards (see Table 2) agree on threshold value of $\mathrm{CO}_{2}$ concentration around $1000 \mathrm{ppm}$. In the EN 16798 (CEN, 2019; Khovalyg et al., 2020), assuming outdoor $\mathrm{CO}_{2}$ concentration at $400 \mathrm{ppm}$, a threshold value of $950 \mathrm{ppm}(\mathrm{TCV}=550+400=950 \mathrm{ppm})$ is considered for the best case relative to Category 1 of high indoor air quality with PFR=10 L/s/pers., and 1200 ppm for Category 2 relative to normal level with PFR=7 L/s/pers. This new European standard EN 16798 published in 2019 has almost halved the ventilation rates for equivalent categories (named IDA1 and IDA2) in the 2007 regulation EN 13779 (Brussels: European Committee for Standardization, 2007).

In France for tertiary premises, the $\mathrm{CO}_{2}$ concentration limit required in the Standard Departmental Health Regulations (RSDT) is 1300 ppm (JORF, 1978). During this pandemic period, a value of 800 to 900 ppm is recommended in many guides. In France, the HCSP (Haut Conseil de la Santé Publique) recommends for public buildings, to implement ventilation actions and ensure the proper functioning of ventilation when the concentration exceeds $800 \mathrm{ppm}$ of $\mathrm{CO}_{2}$ (Haut Conseil de la Santé Publique, 2021). This value relates to a situation in which everyone present is wearing a mask. In circumstances where mask wearing is not possible, the HCSP advises to not exceed $600 \mathrm{ppm}$. REHVA recommends ventilation rates ensuring that $\mathrm{CO}_{2}$ is at or below $800 \mathrm{ppm}$ (Wargocki, 2021). When $\mathrm{CO}_{2}$ concentration exceeds threshold values, one could conclude that the ventilation flow rates are insufficient and aerosol route contamination risk is high. Consequently, if the occupant has a $\mathrm{CO}_{2}$ sensor, he can act by opening the windows, when possible, to provide extra ventilation. However, and as discussed in the next section, fixing a threshold value for $\mathrm{CO}_{2}$ without considering the time of exposure and other parameters such as the quantum production rate, can be very misleading. 
medRxiv preprint doi: https://doi.org/10.1101/2022.01.13.22269234; this version posted January $17,2022$. The copyright holder for this preprint (which was not certified by peer review) is the author/funder, who has granted medRxiv a license to display the preprint in

It is made available under a CC-BY-NC-ND 4.0 International license.

Table 2: Some regulatory guide values for ventilation, and real in situ observations

\begin{tabular}{|c|c|c|c|}
\hline $\begin{array}{l}\text { Territory } \\
\text { or } \\
\text { country }\end{array}$ & $\begin{array}{l}\text { Ventilation Requirement } \\
\text { PFR (L/s/pers.), AFR } \\
\text { (L/s/m²) OR (m²/pers.) }\end{array}$ & $\begin{array}{l}\mathrm{CO}_{2} \text { concentration limits } \\
\text { TCV (ppm), ICONE (-) }\end{array}$ & $\begin{array}{c}\text { In situ observations from the } \\
\text { literature }\end{array}$ \\
\hline 氖 & $\begin{array}{l}\text { Non-residential buildings } \\
\text { (JORF, 1978) } \\
\text { Offices: } \\
\text { PFR=5, OR = 10-15 } \\
\text { Classrooms: } \\
\text { PFR(Child)=4.2; } \\
\text { PFR (adult)=5 } \\
\text { OR = no regulatory } \\
\text { definition, usage = 2-3 } \\
\\
\text { Sales and catering } \\
\text { premises: } \\
\text { PFR = 6,1 }\end{array}$ & $\begin{array}{l}\text { Non-residential buildings: } \\
\text { 1000-1300 ppm } \\
\text { (JORF, 1978) } \\
\text { Nursery, Primary and } \\
\text { elementary schools } \\
\text { (JORF, 2012) : } \\
\text { ICONE = } \\
\text { 0-none, } \\
\text { 1-low, } \\
\text { 2-average, } \\
\text { 3- high, } \\
\text { 4-very high, } \\
\text { 5-extreme air stuffiness }\end{array}$ & $\begin{array}{l}\text { Assessment of } 896 \text { classrooms } \\
\text { and day-care center playrooms } \\
\text { (Ribéron et al., 2016) } \\
\text { Results: } \\
\text { 14\% ICONE=0 } \\
16 \% \text { ICONE=1 } \\
22 \% \text { ICONE=2 } \\
27 \% \text { ICONE=3 } \\
21 \% \text { ICONE= } 4 \text { or } 5 \\
\text { Assessment of } 51 \text { classrooms } \\
\text { in } 17 \text { schools, } 1 \text { school week } \\
\text { Results: } \\
\text { Mean CO }{ }_{2}=1290 \text { ppm, } \\
\text { Peak CO } 2=2220 \text { ppm, } \\
91 \% \text { of the classrooms had } \\
\text { insufficient ventilation } \\
\text { (Canha et al., } 2016 \text { ) } \\
\text { Assessment of } 600 \\
\text { classrooms, } 1 \text { school week } \\
\text { Results: } \\
41 \% \text { of schools having at least } \\
\text { one very confined class } \\
\text { (ICONE } 4 \text { or } 5 \text { ) } \\
\text { (Batiactu, } 2018 \text { ) }\end{array}$ \\
\hline 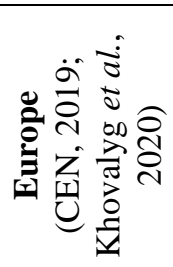 & $\begin{array}{l}\text { All spaces where } \mathrm{CO}_{2} \text { is the } \\
\text { product of human } \\
\text { metabolism } \mathrm{PFR}^{\mathrm{cat} 1}=10 ; \\
\mathrm{PFR}^{\mathrm{cat} 2}=7 ; \mathrm{PFR}^{\mathrm{cat} 3}=4 \\
\text { Classrooms: OR }=2 \\
\text { Offices: OR }=10-15\end{array}$ & $\begin{array}{l}\text { TCV }=550,800,1350 \mathrm{ppm} \\
\text { above the outdoor } \mathrm{CO}_{2} \\
\text { concentration, correspond to } \\
\text { Cat1, Cat2, and Cat3, } \\
\text { respectively }\end{array}$ & $\begin{array}{l}\text { Classrooms: } \\
\text { Peak } \mathrm{CO}_{2} \text { concentrations } \\
\text { ranged from about } 3000 \text { to } \\
6000 \text { ppm. } \\
\text { (Fisk, 2017) }\end{array}$ \\
\hline 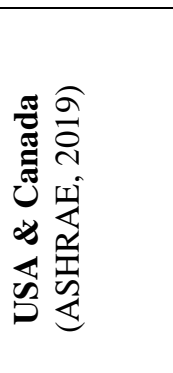 & $\begin{array}{l}\text { Classrooms: } \mathrm{PFR}=5, \mathrm{AFR}= \\
0.6 \text {, OR }=4 \text { (age } 5 \text { to } 8 \text { ), } \mathrm{OR} \\
=2.9 \text { (age } 9 \text { plus) } \\
\text { Lecture classroom: } \mathrm{PFR}= \\
\text { 3.8, AFR }=0,3, \mathrm{OR}=1.5 \\
\text { Offices: } \mathrm{PFR}=2.5, \mathrm{AFR}=0.3 \text {, } \\
\text { OR= } 20 \\
\text { Restaurant: } \mathrm{PFR}=3.8, \mathrm{OR}= \\
1.4\end{array}$ & $\begin{array}{l}\text { Not specified } \\
\text { Reference values given for } \\
\text { dynamic ventilation }\end{array}$ & \\
\hline
\end{tabular}

PFR: People Flow Rate; AFR: Area Flow Rate; OR: default Occupancy Ratio; TCV: Threshold Concentration Value; Cat: Category (Cat1: for spaces occupied by very sensitive and fragile persons with special requirements, Cat2: normal level to be used for new buildings and renovations, Cat3: moderate level may be used for existing buildings); ICONE: Stuffiness index 
medRxiv preprint doi: https://doi.org/10.1101/2022.01.13.22269234; this version posted January 17, 2022. The copyright holder for this preprint (which was not certified by peer review) is the author/funder, who has granted medRxiv a license to display the preprint in It is made available under a CC-BY-NC-ND 4.0 International license .

In schools, if controlled mechanical ventilation is absent, it is necessary to renew the air by opening the windows during the presence of children to avoid too much air confinement, which could be the source of declining pupils' attention and performance, and to avoid bad health effects with serious consequences in the current pandemic period. An experimental survey in 70 classrooms in France in 2013 using $\mathrm{CO}_{2}$ measurement with a light indicator on the sensor of air stuffiness level revealed that $52 \%$ of the 81 surveyed teachers did not open the windows, despite the sensor light alert indicating high level of $\mathrm{CO}_{2}$ concentration, in order to maintain thermal comfort (Dassonville et al., 2013).

Based on $\mathrm{CO}_{2}$ data available in the literature, Fisk (Fisk, 2017) performed a thorough review, which demonstrated widespread failure of ventilation systems to provide the minimum flow rates specified in standards for classrooms. He reported that the maximum peak $\mathrm{CO}_{2}$ concentrations ranged from about 3000 to 6000 ppm.

Based on indoor $\mathrm{CO}_{2}$ concentrations, the ICONE air stuffiness index (Ribéron et al., 2012) has been developed in 2008 by the French Scientific and Technical Center of Building (CSTB) especially for IAQ evaluation in schools. In 2012, the ICONE air stuffiness index has been integrated into the framework for the mandatory monitoring of IAQ in some public buildings in France (IAQ decree $n^{\circ}$ 2012-14 (JORF, 2012). The ICONE takes into account the frequency and intensity of $\mathrm{CO}_{2}$ levels around the threshold values of 1000 and 1700 ppm during normal occupancy of the classroom by children. The confinement level is then expressed by a score scaled in six levels from 0 to 5 . The score 0 corresponds to zero confinement $\left(\mathrm{CO}_{2}\right.$ level always below $\left.1000 \mathrm{ppm}\right)$, this is the most favourable situation. Notes 2 and 3 correspond to low and average confinement, whereas notes 4 and 5 correspond to very high and extreme confinement, level 5 is the most unfavourable situation $\left(\mathrm{CO}_{2}\right.$ concentration always above 1700 ppm during occupancy). In this case, the decree (JORF, 2012) stipulates that additional investigations must be carried out and the local authority (the departmental Prefect) must be informed.

Distribution of ICONE indices in the 896 classrooms and day-care center playrooms from the French IAQ legislation pilot survey (2009-2011) (Ribéron et al., 2016) indicates that in almost half of cases ICONE was higher or equal to 3 (see Table 2). In 2016, the IAQ analysis of 51 classrooms of 17 schools in France (Canha et al., 2016) conducted to the conclusion that in $91 \%$ of the observed classrooms ventilation was insufficient with $\mathrm{CO}_{2}$ concentration above $1300 \mathrm{ppm}$ during $46 \%$ of the occupied period. Furthermore, the French Indoor Air Quality Observatory carried out a vast national survey on indoor atmosphere of French nurseries and schools between 2013 and 2017 (Batiactu, 2018). The measurements were taken during the school period, over five days from Monday to Friday, in more than 600 classes drawn at random throughout the French mainland metropolitan area. The study underlines that the confinement of indoor air is very high, with $41 \%$ of schools having at least one very confined class. The $\mathrm{CO}_{2}$ concentrations lead to ICONE index equal to 4 or 5 thus betraying a ventilation problem in these schools. As mentioned earlier the problem of poor ventilation in classrooms is general and affects many countries (Fisk, 2017). Some measurements of $\mathrm{CO}_{2}$ concentration carried out in classes (elementary classes and University) within the framework of the present work (see section VII-1), indicate that the situation remains worrying. The estimated flow rates either from the monitoring of $\mathrm{CO}_{2}$ concentrations or from direct volumetric flow rates measurements when mechanical ventilation was available, range between one third and one tenth of the regulatory volumetric flow rates.

Fisk (Fisk, 2017) mentions that increasing ventilation with annual costs ranging from a few dollars to ten dollars per person, constitutes less than $0.1 \%$ of typical public spending on elementary and secondary education in the US. Such spending is judged a small price to pay given the evidence of health and performance benefits. This observation is more than ever true in this pandemic period and could be extended to other countries and other sectors than education. 
medRxiv preprint doi: https://doi.org/10.1101/2022.01.13.22269234; this version posted January 17, 2022. The copyright holder for this preprint (which was not certified by peer review) is the author/funder, who has granted medRxiv a license to display the preprint in It is made available under a CC-BY-NC-ND 4.0 International license .

Jan Sundell (July 10, 1943 - May 27, 2019), the former Editor-in-Chief of the Indoor Air Journal, warned, just before his death, the scientific community on the risk of poor ventilation by a long email sent to the new Editor-in-Chief of this journal. This alert takes on its full meaning today and his reflection was published two years after his death, in the pandemic context, as an editorial entitled "VENTILATION: WHY does no one take it seriously?" (Sundell et al., 2021). He mentions that in most of the world, energy has been the top priority and ventilation is wrongly considered as the source of more energy consumption. It is rightly recalled that ventilation has been mainly seen as an engineering problem, whereas in reality, it is a public health topic. Therefore, it is time for public authorities around the world to take hold of this issue through regulatory, educational, and financial tools, so that our schools, our homes, our vehicles, our places of life in general, are finally well ventilated.

For now, we are still at a recommendation stage. In the recent study published in the Lancet Respiratory Medicine (Somsen et al., 2020), the authors recommend to health-care authorities to suppress poorly ventilated public spaces as much as possible to mitigate the spread of SARS-CoV-2.

In its roadmap to improve and ensure good indoor ventilation in the context of COVID-19, WHO (WHO, 2021b) recommends assessment of ventilation flow rates and airflow direction, which are key elements to understand the gap between the ventilation system functionality and the requirements.

\section{VI - Relative risk assessment following variant viral load and contagiousness.}

VI-1. General formulation.

As developed in section II, airborne models of infection usually introduce a dose of exposure $X$ to an infective agent, which, for airborne transmission, is assumed proportional to its viral load $V L$ in the respiratory fluids. Then the probability of infection follows a probability law which must be a strictly increasing function of the dose, varying from zero (no exposure) to one (certainty of developing the disease above a given exposure). In the Wells-Riley model, the Poisson law (Eq. 13) is chosen.

All other parameters being equal (time of exposure, flow rate of fresh air etc..), it is then possible to assess a relative risk between two variants. For the sake of simplicity, we concentrate the following discussion on the initial strain and the $\delta$ variant with different viral loads, $V L_{I S}$ and $V L_{\delta}$ respectively, as done by Rowe et al. (Rowe et al., 2021) for the relative outdoor versus indoor risk.

Let $R$ be the ratio of the doses of exposure between $I S$ and $\delta$ in case of identical situations, from section II (Eq. 1, 2 or 4), $R$ can be reduced to the ratio of viral loads and of the proportionality factors c:

$$
R=\frac{X_{\delta}}{X_{I S}}=\frac{V L_{\delta}}{V L_{I S}} \times \frac{c_{\delta}}{c_{I S}}
$$

It is then easy to demonstrate that relative probabilities of being infected between respectively $\delta$ and IS variants follow the next equation:

$$
P_{\delta}=1-\left(1-P_{I S}\right)^{R}
$$

which for $P_{I S} \ll 1$ reduces to $P_{\delta}=R \times P_{I S}$.

It results that, from the recognized fact that $V L_{\delta} \gg V L_{I S}$, the airborne contamination by the $\delta$ variant is much more efficient than with initial strains for comparable situations, as shown in Figure 1 in the case of $R=10$ and 100 . Note that the same conclusion could apply with the omicron variant 
medRxiv preprint doi: https://doi.org/10.1101/2022.01.13.22269234; this version posted January $17,2022$. The copyright holder for this preprint (which was not certified by peer review) is the author/funder, who has granted medRxiv a license to display the preprint in

It is made available under a CC-BY-NC-ND 4.0 International license.

(and then the subscript $\delta$ should be replaced by $o$ ) but then the $c_{o}$ factor would also explain the higher contagiousness.

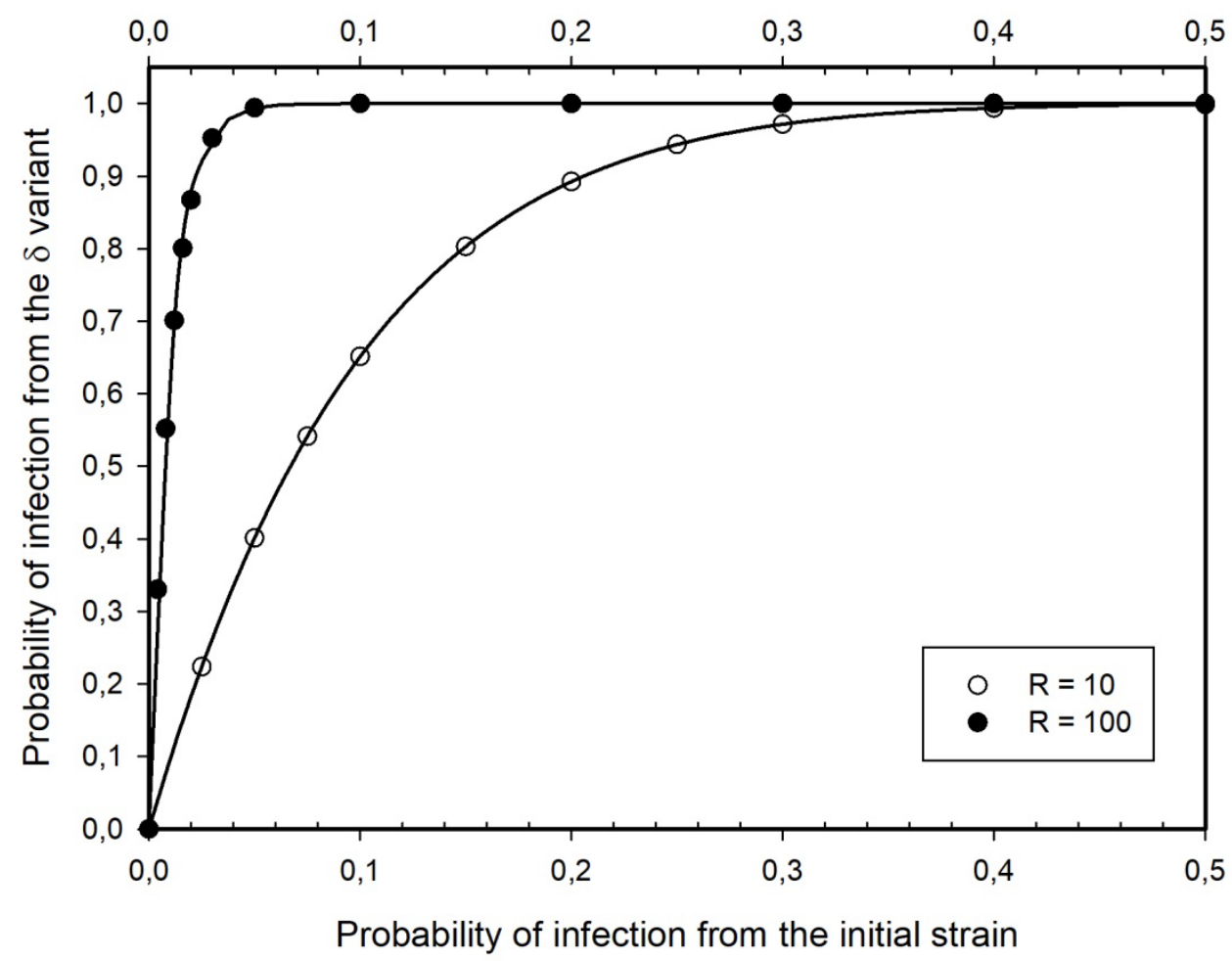

Figure 1: $\delta$ probability of airborne infection versus initial strain for a ratio of viral load in respiratory fluids of 10 and 100 (all other parameters being equal).

VI-2. The case of public access area.

We will examine first the case of an indoor space ventilated following the norm and at stationary state. Then, the dose of exposure is given by equation (12), and, in the Wells-Riley model, the probability of infection follows the Poisson law (13). If the ventilation of the public space $q_{2}$ conforms to the norm per person $q_{\text {norm }}$ :

$$
q_{2}=q_{\text {norm }} \times N_{p}
$$

with $N_{p}$ being the number of persons within the area. This assumption is of course questionable either if the norms are not followed, as discussed in section III, or if the value of $q_{2}$ is fixed constant, independently of $N_{p}$ as it is most often the case.

Assuming a proportion of infectors $r$ we can express the number of infectors as:

$$
I=r \times N_{p}
$$

We will assume that $r$ can be taken as the incidence rate on 7 days and for $10^{5}$ individuals divided by $10^{5}$. This assumes that people tested positive are also infectors, and stay that way for around seven days. These assumptions are questionable but yield probably a good order of magnitude. Strictly speaking it is the prevalence of infectors, including asymptomatic, that should be used for $r$. It is anyway probable that the number of infectors is proportional to $N_{p}$.

Then the dose of exposure reads: 
medRxiv preprint doi: https://doi.org/10.1101/2022.01.13.22269234; this version posted January 17,2022 . The copyright holder for this preprint (which was not certified by peer review) is the author/funder, who has granted medRxiv a license to display the preprint in It is made available under a CC-BY-NC-ND 4.0 International license .

$$
X=\frac{r \times p}{q_{\text {norm }}} \times q \times t
$$

which clearly shows the multifactorial character of the risk. In the case where the ventilation conforms to the norm and for a given value of $r$, the difference between a school, a restaurant and a commercial center comes essentially from the time of exposure $t$. Note that this time is a total time which does not need to be continuous but can be a summation of hourly and daily exposition, due to the fact that the risk is essentially probabilistic. Clearly the difference in quantum production rate between $\delta$ variant and previous strain, plays an enormous role in the dose, and hence in the probability of infection. However, it is clear from equations (13) and (19) that the known parameters on which it is possible to play are the time of exposure $t$, the ventilation rate $q_{2}$ itself, depending on the norm of ventilation $q_{\text {norm }}$ and on the number of persons in the volume, if the total ventilation conforms to the norm.

Note that when $N_{p}$ is not very high and for most of the incidence rate reported, Eq. (18) leads to a number of infectors $I, I<1$, which could seem unrealistic. Instead of the use of Eq. (19) for the dose used with the Poisson probability (hereafter $P_{W R}-$ Eq. (6)) the following value of the probability should be used:

$$
P=\sum_{1}^{n} P_{n} \times P_{W R}(n)
$$

where $P_{n}$ is the probability to have $n$ infectors and $P_{W R}(n)$ the probability of being infected with $n$ infectors.

Then, it can be shown, either by Taylor development or numerical calculations that equations (6) with (19) lead to a very similar result than the more exact calculation (20), assuming that the ventilation rate follows equation (17).

In Figure 2, the curves of equal probability of infection versus the time of exposure and the norm of ventilation (starting at $5 \mathrm{~m}^{3} / \mathrm{h} /$ pers) are shown, for a quantum production rate of $100 \mathrm{~h}^{-1}$, and an incidence rate $r=0.5 \%$. Of course, in the real life, if the ventilation rate is fixed at the maximum space occupancy and not by equation (17) it would result in a smaller probability of infection. Note that this figure results from the assumption that the ventilation rate is proportional to the number of people in the well-mixed space.

In the case of very poor ventilation, we can use Eq. (14 and 6) in order to estimate the risk in a public space as a function of the number of persons in the volume $V$ and of the time of exposure, assuming that at the time $t=0$ the concentration of quantum is zero. This could be for example the case of a poorly ventilated tutorial room (i.e. $q_{2}<<\frac{V}{t}$ ) where the lecture (and hence the student presence) starts at $t=0 ; t$ being the time of exposure. Figure 3 displays the curves of equal probability of infection versus the time of exposure and the number of persons for an incidence rate of $0.5 \%$ and a volume of $150 \mathrm{~m}^{3}$.

Note that the wearing of masks will of course alter these figures by reducing the quantum production rate as well as the quantum inhaled quantity. 


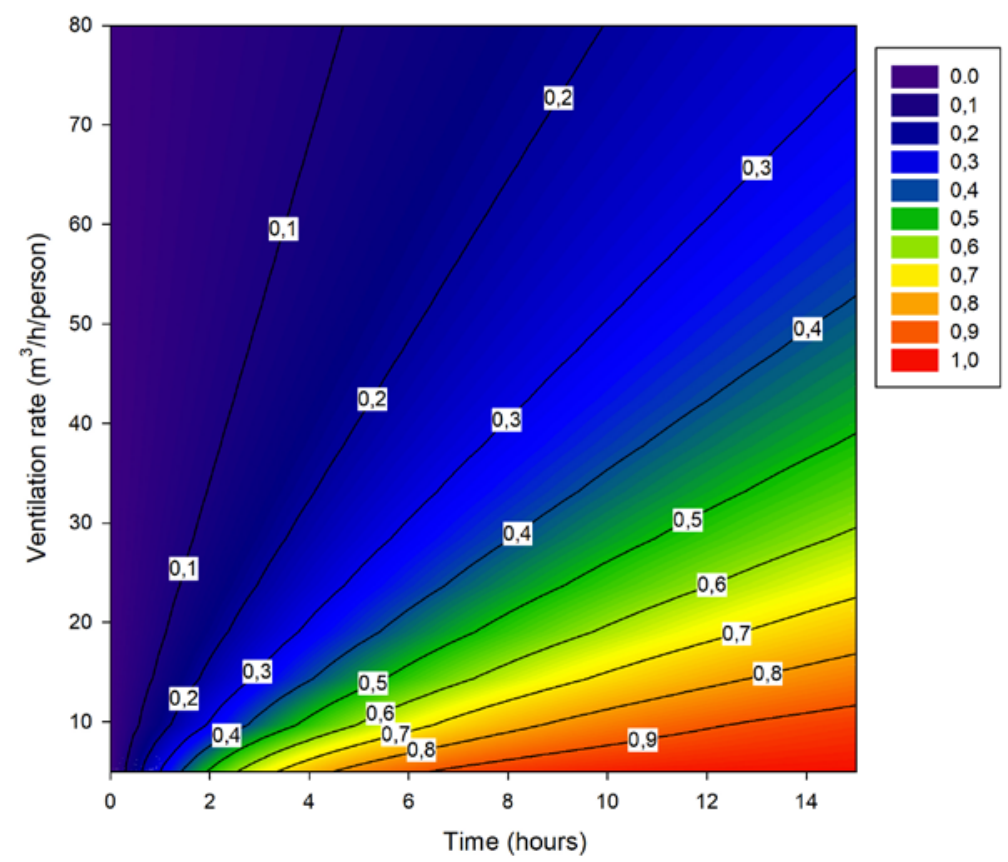

Figure 2: Probability of infection contours as a function of time of exposure and ventilation rate per person assuming a quantum rate of $100 \mathrm{~h}^{-1}$, an expiratory rate of $0.36 \mathrm{~m}^{3} / \mathrm{h}$ and an incidence rate of $0.5 \%$.

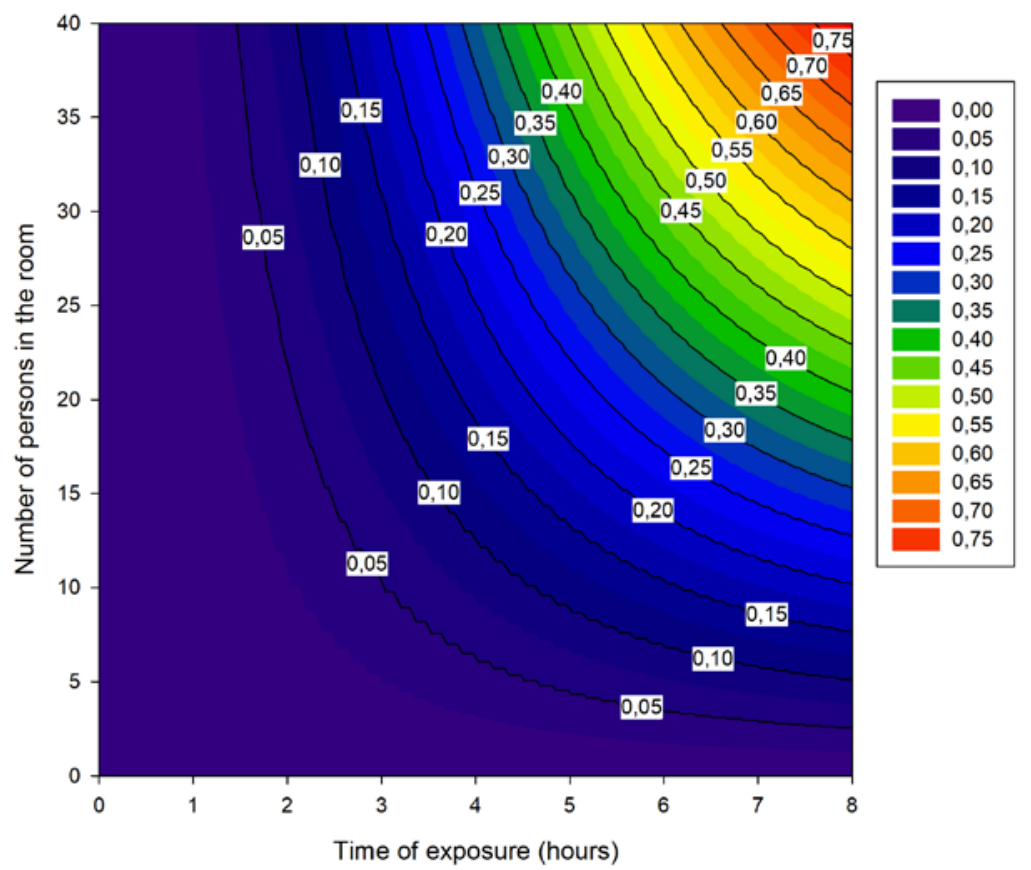

Figure 3: Probability of infection when the ventilation is poor. Calculations are made using an expiratory rate of $0.36 \mathrm{~m}^{3} / \mathrm{h}$, a quantum rate of $100 \mathrm{~h}^{-1}$, an incidence rate of $0.5 \%$ and a room volume of $150 \mathrm{~m}^{3}$ typical of a lecture room.

\section{VII- Analysis of some specific cases}

\section{VII-1. Observations.}

The following Table and Figures gather a series of measurements and observations that we carried out in Autumn 2021 in various environments. Measurements consisted in the determination of the 
medRxiv preprint doi: https://doi.org/10.1101/2022.01.13.22269234; this version posted January 17, 2022. The copyright holder for this preprint (which was not certified by peer review) is the author/funder, who has granted medRxiv a license to display the preprint in It is made available under a CC-BY-NC-ND 4.0 International license.

$\mathrm{CO}_{2}$ time evolution within each room using Non-dispersive infrared (NDIR) $\mathrm{CO}_{2}$ sensors, either an Aranet 4 or a ZG-106 Protronix $\mathrm{CO}_{2}$ monitor. The accuracy of the sensors is $\pm 3 \%$ and $\pm 5 \%$ of reading for the Aranet 4 and the ZG-106 Protronix respectively. The sensors are factory-calibrated and allow raw data logging with time stamps. In order to consider a well-mixed location where measurements were made, sensors were placed at a height between 1 and $2 \mathrm{~m}$ and not near a window or a door and sufficiently far from persons (at least $2 \mathrm{~m}$ ).

Further, when possible the mechanical ventilation was directly measured by using a balometer from ACIN (Flowfinder mk2). The accuracy in flow rate measurements was $\pm 3 \%$ of the reading. Three categories of spaces were investigated including two university lecture rooms (ULR5 and ULR-20) and one pupil schoolroom; two university amphitheaters (UAW and UAE) and finally a restaurant. For each room, the main characteristics are given in Table 3 including the room volume, the number of people present during the experiments, the maximum allowed people from which the regulatory ventilation can be determined (according to French regulation (JORF, 1978) $18 \mathrm{~m}^{3} / \mathrm{h} /$ person for lecture rooms and amphitheaters; $15 \mathrm{~m}^{3} / \mathrm{h} /$ person for the schoolroom and $22 \mathrm{~m}^{3} / \mathrm{h} /$ person for the restaurant) and the ventilation type. The duration and time step of each investigation are also mentioned. A time step of 10 minutes was sometimes fixed in accordance with the French IAQ decree $n^{\circ}$ 2012-14 (JORF, 2012) for five-day monitoring to determine the ICONE index.

The $\mathrm{CO}_{2}$ time evolution followed the standard law:

$$
\left[\mathrm{CO}_{2}\right]-\left[\mathrm{CO}_{2}\right]_{0}=\left(\left[\mathrm{CO}_{2}\right]_{\infty}-\left[\mathrm{CO}_{2}\right]_{0}\right)\left\{1-\exp ^{-\frac{Q t}{V}}\right\}
$$

where $\left[\mathrm{CO}_{2}\right]_{0}$ is the $\mathrm{CO}_{2}$ concentration, expressed in ppm, at the beginning of the analytical fit $(t=0)$, $\left[\mathrm{CO}_{2}\right]_{\infty}$ is the stationary $\mathrm{CO}_{2}$ concentration $(\mathrm{t}=\infty), Q$ the ventilation flow rate $\left(\mathrm{m}^{3} / \mathrm{h}\right), V$ the room volume and $t$ the time at which the measurement was carried out. From this equation, it is straightforward to determine the ventilation rate $Q$ from an exponential fit of the measurement when the volume $V$ is known, at least when $\left[\mathrm{CO}_{2}\right]_{\infty}$ is not ill-defined, a situation that occurs when the number of people constantly changes with time like in the restaurant (see Table 3).

Table 3: Ventilation measurements for various environments with their own main characteristics

\begin{tabular}{|c|c|c|c|c|c|c|}
\hline Room & ULR5 & ULR20 & Schoolroom & UAW & UAE & Restaurant \\
\hline Volume $\left(\mathrm{m}^{3}\right)$ & 136 & 402 & 173 & 900 & 1035 & -- \\
\hline People/max & $28 / 30$ & $67 / 68$ & $30 / 30$ & $40 / 142$ & $95 / 163$ & var./120 \\
\hline $\begin{array}{l}\text { Regulatory } \\
\text { volumetric flow } \\
\text { rate }\left(\mathrm{m}^{3} / \mathrm{h}\right)\end{array}$ & 540 & 1224 & 450 & 2556 & 2934 & 2640 \\
\hline $\begin{array}{l}\text { Ventilation } \\
\text { system }^{\mathrm{a}}\end{array}$ & $\mathrm{U}$ & B-dyn & $\mathrm{H}$ & B & B & B or B-dyn \\
\hline $\begin{array}{l}\text { measurement } \\
\text { duration/time } \\
\text { step (min) }\end{array}$ & $80 / 10$ & $90 / 5$ & 7days/10 & 56/ var. & $55 / 1$ & 5days/5 \\
\hline $\begin{array}{c}\text { Volumetric } \\
\text { flow rate } \\
\text { from } \mathrm{CO}_{2}\left(\mathrm{~m}^{3} / \mathrm{h}\right)\end{array}$ & 53 & $1124 / 450$ & $50-100$ & 2576 & 1219 & -- \\
\hline $\begin{array}{c}\text { Measured } \\
\text { volumetric flow } \\
\text { rate }\left(\mathrm{m}^{3} / \mathrm{h}\right)\end{array}$ & -- & $\begin{array}{c}\text { Max/Min }= \\
1187 / 200\end{array}$ & -- & -- & 1009 & $\begin{array}{c}\sim 500 \text { at } 15 \mathrm{~h} \\
\text { am }\end{array}$ \\
\hline
\end{tabular}

${ }^{\text {a }}$ B: bidirectional ventilation; B-dyn: bidirectional dynamic ventilation; U: unidirectional ventilation; $\mathrm{H}$ : hybrid ventilation

The $\mathrm{CO}_{2}$ time evolutions are illustrated in Figure 4-(a-d) where the reference of the $\mathrm{CO}_{2}$ concentration has been taken as the outdoor usual value of $400 \mathrm{ppm}\left[\mathrm{CO}_{2}\right]_{\text {ext }}$ instead of considering 
medRxiv preprint doi: https://doi.org/10.1101/2022.01.13.22269234; this version posted January 17, 2022. The copyright holder for this preprint (which was not certified by peer review) is the author/funder, who has granted medRxiv a license to display the preprint in It is made available under a CC-BY-NC-ND 4.0 International license.

$\left[\mathrm{CO}_{2}\right]_{0}$ as the reference. This makes to the readers easy to return to the absolute value since the initial value $\left[\mathrm{CO}_{2}\right]_{0}$ is never the same from one test to another.

Figure 4-a compares two lecture rooms (ULR5 and ULR20, see Table 3). These lecture rooms are at a University building over 50 years old, which has not yet undergone an energy retrofit. The ULR5 is equipped with air intake vents installed in window frames. As the building envelope is not airtight and since the toilets facilities, equipped with mechanical air exhaust, are far away from ULR5, little fresh air enters by the windows intake vents. In addition, exhaust flow rates at the level of the building are too low in comparison to the regulatory ventilation needs. This explains the observed very poor IAQ with maximum concentration of $\mathrm{CO}_{2}$ exceeding $5000 \mathrm{ppm}$. This trend has been confirmed in a similar lecture room (ULR4, not shown for brevity) where $\mathrm{CO}_{2}$ concentration measurements during five consecutive scholar days lead to an air stuffiness index ICONE of 4, i.e. very high confinement.

The ULR2O is a lecture room, among three rooms of the same previous building, which were fitted more than ten years ago with a common dynamic two-way ventilation system, using the level of $\mathrm{CO}_{2}$ in the exhaust circuit to control the ventilation flowrate. This system sized for a maximum flow of $1187 \mathrm{~m}^{3} / \mathrm{h}$ (for occupancy capacity of 68 students plus a teacher, i.e. PFR $=17.2 \mathrm{~m}^{3} / \mathrm{h}$ close to the French regulatory value of $18 \mathrm{~m}^{3} / \mathrm{h}$ ). It is however set at a minimum flow of $200 \mathrm{~m}^{3} / \mathrm{h}$ during the unoccupied hours, and is manually switched off during holidays. In this room, in 22/01/03, while the ventilation was still off after holidays, a maximum concentration of $3300 \mathrm{ppm}$ was registered after one hour of presence of 64 persons inside. The corresponding evolution is not given for brevity. During normal operation of the ventilation system of full occupied ULR20, the $\mathrm{CO}_{2}$ level does not exceed 1700 ppm as illustrated in Figure 4-a. This threshold corresponds to a Category 3 classification (moderate level may be used for existing buildings) in the UE regulation (CEN, 2019) and is above the French limit value of 1300 ppm (JORF, 1978). However, this remains acceptable in comparison with the previous ULR5 case.

Figure 4-b presents $\mathrm{CO}_{2}$ evolutions in two lecture halls (UAE and UAW). UAE is, as previously, over 50 years old, whereas UAW is a modern new building. One can observe that in UAE the $\mathrm{CO}_{2}$ concentration reaches a high value of $2100 \mathrm{ppm}$ after a lecture of one hour in the presence of 95 persons. This corresponds to PFR $=13 \mathrm{~m}^{3} / \mathrm{h} /$ pers. Note however that when the lecture hall is full, the PFR would then be equal to $8 \mathrm{~m}^{3} / \mathrm{h} /$ pers., which is very far from the regulatory value. On the opposite, UAW seems very well ventilated since the $\mathrm{CO}_{2}$ concentration did not exceed $600 \mathrm{ppm}$ in the presence of 40 persons. The deduced volumetric flow rate was as high as $2576 \mathrm{~m}^{3} / \mathrm{h}$, which results in PFR $=18 \mathrm{~m}^{3} / \mathrm{h} /$ pers. when considering the UAW maximum capacity of 142 . Therefore, this lecture hall complies with French regulations, and probably when it is full, the $\mathrm{CO}_{2}$ would be in the regulatory range 1000 to 1300 ppm (JORF, 1978). However, we can regret, for energy comsumption reasons, the apparent absence of flow rate control as a function of the occupancy density.

Figure 4-c shows the $\mathrm{CO}_{2}$ time evolution acquired during one full week in a classroom at a school in the city of Rennes (Department of Ille et Vilaine, France). The building is old (built almost a century ago) and has not benefited from an energy retrofit. The considered schoolroom receives 30 pupils 7years-old. The insert in Figure 4-c gives an example of a $\mathrm{CO}_{2}$ rise from which the ventilation rate could be estimated. Since, the flow rate was found quite small, the measurements presented some dispersion from one day to the other. However, we always found a ventilation flow rate in the range $50-100 \mathrm{~m}^{3} / \mathrm{h}$, which is very far below the regulatory flow rate for a schoolroom with a maximum occupancy of 30 persons (i.e. $450 \mathrm{~m}^{3} / \mathrm{h}$ according to the French regulation (Agence Régionale de la Santé - Bretagne, 1997; JORF, 1978)). The corresponding air stuffiness index (JORF, 2012; Somsen et al., 2020) is ICONE=4, corresponding to very confined class. This observation joins those of the 
medRxiv preprint doi: https://doi.org/10.1101/2022.01.13.22269234; this version posted January 17, 2022. The copyright holder for this preprint (which was not certified by peer review) is the author/funder, who has granted medRxiv a license to display the preprint in It is made available under a CC-BY-NC-ND 4.0 International license .

French air quality observatory (Batiactu, 2018) and different literature studies of ventilation state in schools in France (Canha et al., 2016; Ribéron et al., 2016) and elsewhere, particularly in Europe or USA (Fisk, 2017) (see Table 2).
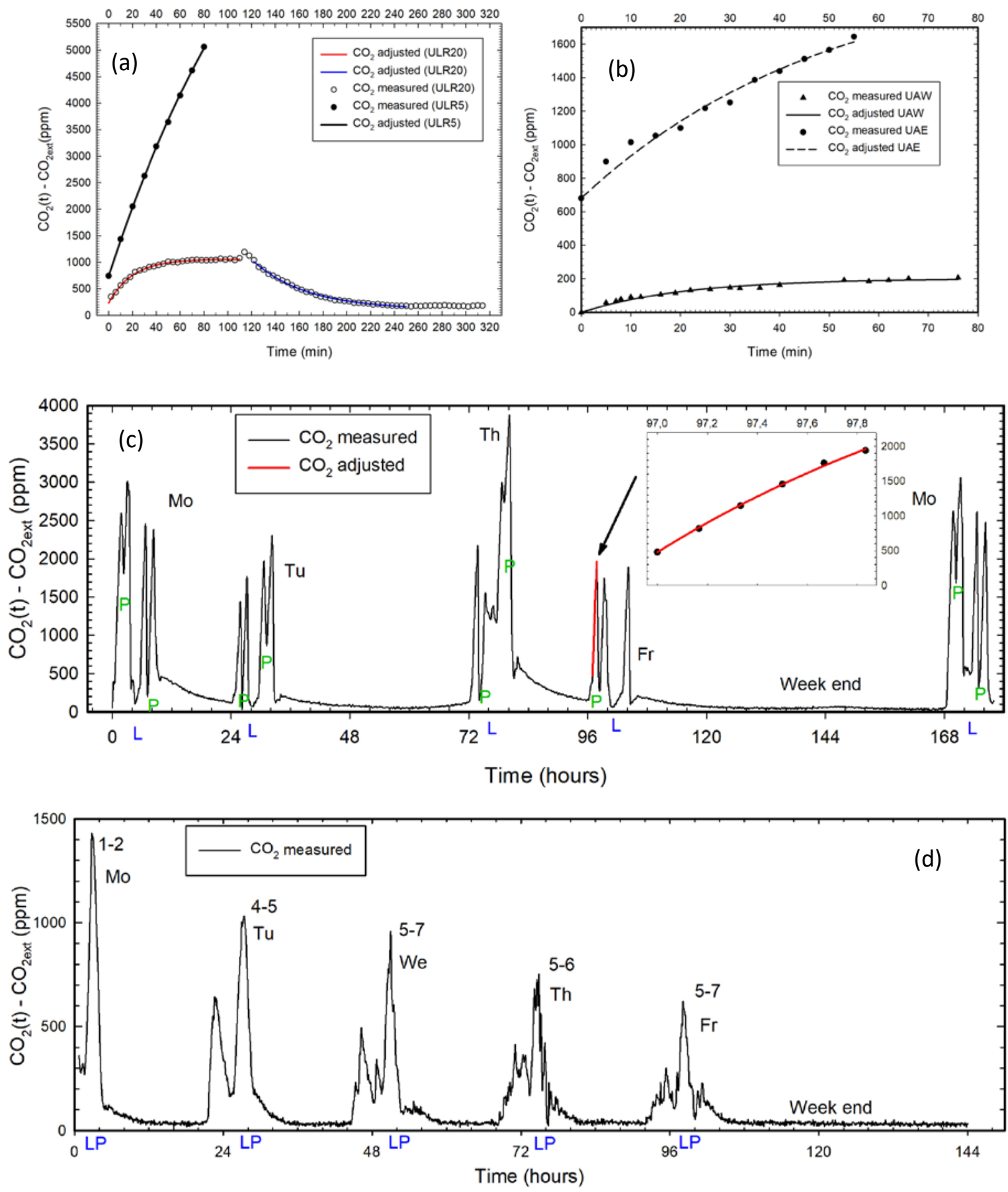

Figure 4: $\mathrm{CO}_{2}$ time evolution within examples of indoor spaces - complementary information are given in Table 3: (a) two lecture rooms (ULR5 and ULR20); (b) two lecture halls (UAE and UAW); (c) schoolroom over one week; (d) restaurant over a week (numbers close to the $\mathrm{CO}_{2}$ peaks represent the strength of the wind in Beaufort scale). 
medRxiv preprint doi: https://doi.org/10.1101/2022.01.13.22269234; this version posted January 17, 2022. The copyright holder for this preprint (which was not certified by peer review) is the author/funder, who has granted medRxiv a license to display the preprint in It is made available under a CC-BY-NC-ND 4.0 International license.

Finally, we carried out a $\mathrm{CO}_{2}$ monitoring during a week (Figure 4-d) in a modern restaurant located in a coastal location of the Department of "Côtes d'Armor" in France. We used two Aranet sensors each one located in one of the two lunchrooms of the restaurant which communicate to each other through a large aperture. The two sensors were approximatively at a distance of $10 \mathrm{~m}$ to each other and demonstrate a similar $\mathrm{CO}_{2}$ concentration along the week. This is a strong demonstration that for this studied case that the well-mixed assumption holds. Interestingly, the restaurant is exposed to the wind, which can cause large variations in air renewal flow rates. Observations correlate strongly with an enhancement of ventilation with the strength of the wind (and inversely for $\mathrm{CO}_{2}$ concentration) which is shown on each peak of the figure in Beaufort scale (Bt $=1-2$ on Monday; 4-5 on Tuesday; 5-7 on Wednesday; 5-6 on Thursday and 5-7 on Friday). Not indicated is the direction of the wind which has been changing continuously along the week. The high variability in peak $\mathrm{CO}_{2}$ from day to day can be clearly seen in Figure 4-d and wind effect on the level of airing appears obvious. On Monday, when there was no wind, a maximum concentration of 1800 ppm was recorded, which is a high level compared to the French public health committee recommendations to not exceeding 600 ppm in situations in which everyone present is NOT wearing a mask (Haut Conseil de la Santé Publique, 2021).

Furthermore, in essence the restaurant is a place where conditions are continuously variable (customers do not arrive at the same time, doors open frequently) and it is not easy to establish stable conditions allowing to determine air flow rates from $\mathrm{CO}_{2}$ concentrations. Moreover, even if we do not have the confirmation, it is very likely that the bidirectional ventilation is dynamic, which makes air flow rates variables. The in-situ volumetric flow rate measurements done on Friday at $3 \mathrm{pm}$ in customers space (lunchrooms and bar), lead to a total air flow rate around $500 \mathrm{~m}^{3} / \mathrm{h}$. The hood in the kitchen and the related compensation grille, placed on opposite exterior wall, have probably an effect on flow patterns in lunchrooms, as the kitchen door is kept open during lunchtime. Since our objective was to evaluate the potential risk of contamination in a space where masks fall, we did not focus too much on a precise determination of the ventilation rate considering the above mentioned difficulties. Rather we concentrated on the $\mathrm{CO}_{2}$ levels achieved every day (see discussion in section VII-2).

Through all above observations, the poor ventilation of the premises is evident and agrees with the observations of various bibliographical sources recalled in Table 2, and not only in France as revealed by the thorough review from Fisk (Fisk, 2017).

VII-2. Risk assessment.

For the various situations described above it is important to derive a risk probability for an exposed person (susceptible) as a function of the observation of $\mathrm{CO}_{2}$ concentration. It is possible to show that, from a statistical point of view and a large number of persons, the dose can be written as:

$$
X=\int_{t 0}^{t 1} \frac{\Delta C O_{2}(t)}{\mathrm{CO}_{2, \text { exh }}} \times r \times q \times d t
$$

This relationship is valid for any situation including environments with very poor ventilations and transient situations as well as stationary states $\left(\frac{\partial \Delta \mathrm{CO}_{2}}{\partial t}=0\right)$. It does not make any assumption on the ventilation rate. It can be extended to include a virus lifetime but we omit it for sake of simplicity as it does not change the conclusions. Parameters $r$ and $q$ have respectively the same definition than in the previous sections, $\Delta t=t 1-t 0$ is the time of exposure of the susceptible, $\mathrm{CO}_{2, \text { exh }}$ the 
medRxiv preprint doi: https://doi.org/10.1101/2022.01.13.22269234; this version posted January 17, 2022. The copyright holder for this preprint (which was not certified by peer review) is the author/funder, who has granted medRxiv a license to display the preprint in It is made available under a CC-BY-NC-ND 4.0 International license .

quantity of $\mathrm{CO}_{2}$ in the air exhaled by a human (taken equal to $40000 \mathrm{ppm}$ ), $\triangle \mathrm{CO}_{2}$ the difference between the measured $\mathrm{CO}_{2}$ in ppm and the outdoor natural level measured with sensors.

We can define a mean value of "human" $\mathrm{CO}_{2}$ for the time of exposure $\Delta t$ by:

$$
C O_{2, \text { mean }}=\frac{\int_{t 0}^{t 1} \Delta \mathrm{CO}_{2}(t) \times d t}{\Delta t}
$$

Then, the dose can be written:

$$
X=\frac{\mathrm{CO}_{2, \text { mean }}}{\mathrm{CO}_{2, \text { exh }}} \times r \times q \times \Delta t
$$

which highlights, beside the $\mathrm{CO}_{2}$ concentration, the importance of the time of exposure $\Delta t$ and of the number of infectors. Note that the remarks made in section VI-2 for the $r$ value remain valid. If a healthy subject is exposed to successive doses $X_{i}$ corresponding to different periods of exposure, $\Delta t_{i}$ then the total dose is just the sum of the successive doses; the risk is cumulative:

$$
X=\sum_{i} X_{i}
$$

Following these formulas, we can deduce some risk probabilities corresponding respectively to the situations described in section VII-1. They are summarized in Table 4:

Table 4: Probability of infection for various scenarios

\begin{tabular}{ccccccccc}
\hline & \multicolumn{2}{c}{ school } & \multicolumn{2}{c}{ restaurant } & UAE & UAW & URL5 & URL20 \\
\hline & No mask & mask & 1 meal & 5 meals & 1 Lect & 1 Lect. & 1 Lect. & 1 Lect. \\
$\mathrm{P}$ & 0,19 & 0,021 & $0,004<X<0,009$ & 0,03 & 0,01 & 0,001 & 0,03 & 0,01 \\
\hline
\end{tabular}

In this table we have made the choice to use a single value for $r$ and $q$ of respectively $0.3 \%$ and $10 \mathrm{~h}^{-1}$, although the value of $r$ was probably slightly lower (but not significantly) at the restaurant location. Mostly for the values of calculated doses, the probability for an healthy susceptible to be infected is just nearly equal to the dose, due to its low value as explained previously. Therefore, the influence of changing the values of $r$ and $q$ can be easily estimated by a proportional calculation, as long as the dose remains not too high.

Some points in this table merit to be highlighted:

- For the school, the situation would be catastrophic without considering the risk reduction due to the mask. However, the precise quantitative impact of mask wearing is difficult to evaluate as discussed in the present paper. Also the social acceptability of mask wearing by children merits to be discussed.

- For the restaurant/bar, we have considered the fact that it is made for workers who spend a short time at lunch (around one hour) and the risk is negligible for a single meal. if the restaurant is used on a daily basis this figure could be raised to a few percent. However, the calculation does not consider that the mask is used in the restaurant, except for eating of course. In any case our observation and calculation show that the restaurant is not a place of especially high risk, which questions on public policy in this field.

- For the other premises, which are all located at the university, observations show a considerable dispersion. The risk can be very high for a lecture room very poorly ventilated (case URL5 of table 4) as well as reasonably low in well ventilated area (case UAW). It must also be considered that for the university premises we have not 
medRxiv preprint doi: https://doi.org/10.1101/2022.01.13.22269234; this version posted January 17, 2022. The copyright holder for this preprint (which was not certified by peer review) is the author/funder, who has granted medRxiv a license to display the preprint in It is made available under a CC-BY-NC-ND 4.0 International license.

considered either mask wearing or the cumulative aspect of the dose. As these two parameters play in an opposite way, they probably counter-balance. It remains that in poorly ventilated area the risk is high.

\section{Implications of increased airborne contamination for health policy}

The previous sections highlight the multiparameter character of the risk, through the time of exposure and the concentration of airborne infectious particles, this last quantity being dependent on the proportion of infectors, clearly linked to the incidence rate $\boldsymbol{r}$, with their emission rate of quanta and to the ventilation rate. With new variants such as $\delta$ or o (omicron), the quantum emission rate $q$ can be estimated orders of magnitude higher than with the original strain due to viral load or microbiological characteristics. Then, the spread of the virus should be mainly airborne even for close contact. According to the model presented above, the transmission is then much more efficient. This is in fact observed (Institut Pasteur, 2021) even if, fortunately, it seems that the new variants are much less lethal than the original Wuhan strain. However health policies have not been sufficient to slow down efficiently the contamination, especially in western Europe. With more dangerous variants or new respiratory diseases, either more lethal or more contagious or both, new intervention measures must be considered. In the $\delta$ or o variant cases, the models and concepts presented in the precedent sections and the experimental measures reported lead us to derive implications for health policy. These implications depend partly on the country and the climate. Such an exercise has already been done previously by leading scientists of the field (Morawska et al., 2020) but it seems that it has not been sufficiently considered by health policies. While we do think that it is necessary to develop a variety of engineering solutions already described elsewhere (Morawska et al., 2020) we insist that this should be done only if, concerning mitigation measures, authorities change their mind in matter of priority.

Amongst the various interventions of public policy discussed below we focus on the nonpharmaceutical ones. We will first consider interventions targeting directly air quality, i.e., mask, air filters and sterilizers, and ventilation. In this context we will also discuss the influence of the way of life, which depends of course on the country and the climate, and could lead to take very immediate measures and recommendations with, in our opinion, strong positive consequences. We will then turn to interventions that are not targeting directly air quality but nevertheless have implications on air quality (e.g., living conditions during lockdown) or which effectiveness is not independent of our understanding of contamination routes and viral load (e.g., contact tracing).

Such discussion is all the more needed that vaccine efficiency has been reported dropping far from $100 \%$ with time and variants for most vaccines, including Pfizer, and that their ability to stop transmission by asymptomatic infection is questionable (Hacisuleyman et al., 2021; Servellita et al., 2021). It is most probable that vaccination alone will not be enough to stop the epidemic spreading via airborne contamination, because present vaccines do not provide a $100 \%$ immunity, especially with new variants such as omicron, although it will result in a strong reduction of the gravity of infection and of its consequences. Beside the need of a large vaccination of people at risk (elderly, diabetic, overweight etc.) to reduce illness degree of severity, it is clear that mitigation measures especially toward the problem of indoor air quality should be highlighted: checking of HVAC (Heating, Ventilation, Air Conditioning) systems, ventilation, air monitoring or development of high flux air sterilizers. New variants or new respiratory viruses in the future require a change of paradigm in this field as stated by Morawska (Morawska et al., 2021). However, many of these measures, especially when they require technological development, will not be possible on the very short time and 
medRxiv preprint doi: https://doi.org/10.1101/2022.01.13.22269234; this version posted January 17, 2022. The copyright holder for this preprint (which was not certified by peer review) is the author/funder, who has granted medRxiv a license to display the preprint in It is made available under a CC-BY-NC-ND 4.0 International license .

immediate measures directed toward people information and the way of life must also be taken immediately.

VIII.1 Can Masks be sufficient to address airborne transmission?

When air quality is deficient, especially in indoor situation, wearing a mask is certainly highly useful (Leung et al., 2020; Milton et al., 2013; Wang et al., 2021a), but again their efficiency (especially for surgical ones) is not such that it could be the solution alone. Using equation 4 and results of (Weber et al., 1993; Rengasamy et al., 2014), it can be shown that wearing the mask reduces the quantum production rate by a factor of three, and reduces the dose inhaled flow rate of the same factor. If a leak flow rate assumed equal to $30 \%$ is introduced, it is then possible to calculate that the risk probability $\mathrm{P}$ is decreased by a factor of ten. However, with new variants the increase of the quantum production rate could counterbalance this advantage.

It must also be noticed that there are various kinds of masks. In most countries, the choice of surgical masks in the general population has been made, although it is known that they are much less efficient than N95 respirators (Rengasamy et al., 2014; Balazy et al., 2006) as well for the leak around the face than for the filtration of the smallest particles. In some situations, the public should be informed of the better choice, depending on the air quality (see sub-section VIII-7). Information on the way of wearing masks should also be made as too many people are seen wearing it under the nostrils.

Moreover, and as stated above, if mask wearing is a necessity in the context of a pandemic such as COVID-19, social acceptability on the long term is most doubtful. Therefore, beyond protecting ourselves and others with masks in certain indoor conditions, we must also take corrective measures to improve air quality.

It can therefore be concluded that wearing a mask alone, although it is useful, is insufficient to counterbalance the very high viral load due to delta variant or microbiological characteristics of omicron.

VIII.2 Checking and improving ventilation

Ventilation of buildings has been for centuries a natural ventilation, i.e. a renewal of fresh air by inlet (leak of joinery frames, open windows etc.) and outlet openings (example of chimney), allowing entrance and circulation of fresh air. As such it was not controlled and most often resulted in a high flow rate and higher energy consumption for heating in cold places. In hot countries, buildings used natural cooling, which takes advantage of cross-breezes and, by construction, minimize solar impact. Warm air was directed away from living quarters, with open porches allowing admitting cool fresh air, preventing its solar heating. Sometimes evaporative cooling of water was used (Albadra and Lo, 2014).

With the $20^{\text {th }}$ century, things changed with the advent of HVAC technologies. Ventilation is an essential part of a HVAC system and in order to save energy the admission of fresh air is in general minimized at the lowest value considered as compatible with air quality.

As seen in the previous sections, indoor air quality is now recognized as a concern for public health and is addressed by building norms. However, air quality policy has mainly considered the issue of chemical or particulate matter pollutants (see section V), excepted in the context of health care buildings, such as hospitals (Kowalski, 2007). It is now time to address the question of airborne pathogens "pollution" in the general population and its consequences for respiratory diseases. This 
medRxiv preprint doi: https://doi.org/10.1101/2022.01.13.22269234; this version posted January 17, 2022. The copyright holder for this preprint (which was not certified by peer review) is the author/funder, who has granted medRxiv a license to display the preprint in It is made available under a CC-BY-NC-ND 4.0 International license .

will need a considerable change in the norms and recommendations for buildings, since, from this point of view, they are still in their infancy.

Up to now construction has been centered on three objectives:

- The thermal comfort of (occupant) with strong improvement concerning the physiological comfort, which is dependent of the hygrometry, wall and window insulation, temperature. Thermal comfort requires heating or cooling depending on the season and location.

- Indoor air quality which means avoiding pollutants, but as stated above, without considering the fact that infinitesimal concentration of pathogens could be enough to spread a disease.

- Saving of energy in the context of the climate challenge (greenhouse effect) and of the increasing price of energy.

We recommend, in the context of new buildings and retrofit that is put in place, the in-situ verification of regulatory flow rates. This is often not done, because the regulations do not require $i t$, as it is the case in France in the context of the regulation RT2012 (Ministère de la transition écologique, 2020a). It follows, as it has been seen in the examples presented in this work, introduced fresh airflows being much lower than the regulatory values. The ventilation professionals (French Ventilation Professionals, 2018) made an alarming report on the failure of the ventilation systems and demanded in 2018 that a certificate of receipt of the ventilation systems be put in place, like the certificate of receipt of airtightness of building envelopes mandatory in RT 2012. The next regulation RE2020 (Ministère de la transition écologique, 2020b) applicable in January 2022 for residential buildings, takes a step forward by setting up an obligation to measure ventilation flow rates. However, one can make the criticism that this point is not subject to a building acceptance certificate. The other criticism is that the verification of the airflows is not entrusted to an independent control office since the ventilation system installers can make the flow rates measurements themselves. The Sweden experience of the OVK (Obligatory Ventilation Control) in place since 1991 (Boverket - the Swedish National Board of Housing Building and Planning, 2021) is shared in REHVA site (Ekberg, 2021) as an example to be followed by European countries and elsewhere. The Sweden regulation specifies that the first inspection of the ventilation system is mandatory when it is taken into operation. Then, regular inspections are mandatory every 3 or 6 years, depending on the building type ( 3 years interval for pre-schools, schools, and health-care buildings). Jan Sundell has fought for decades to put in place this OVK in Sweden, but he mentions in his last editorial letter (Sundell et al., 2021) that it is not enough. HVAC engineers must be properly educated to the question of the indoor air quality, and its public health issues. He wrote in 2019 "today in the United States or China, students are not taught properly about ventilation. They are taught to design air conditioning !!!"

On the short term, and when a global mechanical ventilation system is in place, increasing the ventilation flow rate should be achieved when possible. In 2009, Nielsen (Nielsen, 2009) analyses experimentally the transport process of particles and tracer gases and show that a high flow rate (i.e., $\mathrm{ACH}$ from 6 to $12 \mathrm{~h}^{-1}$ ) to the ventilated space reduces the level of viruses and bacteria in this space, without draught effect if large supply areas in the ceiling or in the wall are used. Of course, this has an energy cost, as discussed in section $V$, but it has to be put in balance with the considerable cost (and economy impact) of present public policy in most countries. This is particularly true in public buildings. Of course, it can be a transient measure, to be taken when the incidence rate of the disease becomes too high. 
medRxiv preprint doi: https://doi.org/10.1101/2022.01.13.22269234; this version posted January 17, 2022. The copyright holder for this preprint (which was not certified by peer review) is the author/funder, who has granted medRxiv a license to display the preprint in It is made available under a CC-BY-NC-ND 4.0 International license.

In some cases like offices, classrooms, aircraft or cabins, where people stand at the same desk/place for a large part of their time, other solutions than global ventilation could be adopted, as personalized, or piston ventilation (Cao et al., 2014). Computational Fluid Dynamics have shown recently that personalized ventilation performed the best to prevent cross-infection (Su et al., 2022) compared to mixing ventilation, followed by displacement ventilation, impinging jet ventilation, stratum ventilation and wall attachment ventilation.

VIII- 3: high flux air filters and sterilizer.

As discussed previously, sterilizing and filtering air has the same effect than fresh air ventilation. In his book of 1955 (Wells, 1955), Wells recommended a ventilation rate per pupil at school of $510 \mathrm{~m}^{3} / \mathrm{h}$ which is an enormous value, much higher (an order of magnitude) than any current norm in any country. Such flow rates would imply an important energy consumption. For example, for a class of thirty pupils, such a flow rate will lead to an energy consumption of around $300 \mathrm{kwh}$, for a heating above outdoor temperature of $15{ }^{\circ} \mathrm{C}$ and a time of 5 hours. This could be significantly reduced by using double flux ventilation, but represents anyway a high financial cost. Probably aware of this difficulty, Wells proposed a variety of solutions to sterilize airflows, and more particularly the use of UV lamps. Nowadays the insufficient ventilation of schools and nurseries is largely recognized (ICEB, 2014).

In order to remove infectious droplets of air, a solution can be the use of HEPA (High Efficiency Particulate Air) filters. This type of air filter can theoretically remove at least $99.97 \%$ of any airborne particles with a size of 0.3 microns $(\mu \mathrm{m})$. This aerodynamic diameter specification of 0.3 microns corresponds to the worst size case, larger or smaller particles being trapped more efficiently due to the competition between two modes of trapping.

To ensure that a HEPA filter is working efficiently, the filters should be inspected quite regularly, and changed at required time intervals. A clogged HEPA filter can have a large leak rate through the peripherical gasket (Casas, 2019). The pressure drop through the filter can result in a rather large energy consumption, beside the cost of the system for the equipment and its maintenance.

Air purifiers have been for a long time on the market, and the COVID-19 crisis has led to a considerable development of air sterilizers that use, amongst others, UV germicidal power, which is well documented for viruses (Lytle and Sagripanti, 2005). It can be shown by calculation that the required UV power is rather small (King, 2013) in order to efficiently sterilize large air flow rates. However, most of the sterilizer systems found on the market treat a much too low air flow rate, although there are no technical reasons for that. The reason is probably that most often this kind of apparatus includes other functions such as VOC (Volatile Organic Compounds) treatment, and particle filters such as HEPA, which results also in a higher cost.

Therefore, a development of cheap air treatment units dedicated specifically to sterilization of very high air flux is clearly needed on the mid-term.

\section{VIII.4 Airborne close contact.}

As discussed in section IV it is now recognized that the close contact risk, except intimate, i.e. for a distance $<0.6 \mathrm{~m}$, is essentially airborne. Here again the exposure time is essential as shown by 
medRxiv preprint doi: https://doi.org/10.1101/2022.01.13.22269234; this version posted January 17, 2022. The copyright holder for this preprint (which was not certified by peer review) is the author/funder, who has granted medRxiv a license to display the preprint in It is made available under a CC-BY-NC-ND 4.0 International license.

the work of Cortellessa et al. (Cortellessa et al., 2021). It has been shown (Zhang et al., 2020b) that, in many situations, contact between two individuals last less than fifteen minutes and in this context, it can be inferred that the risk drop to a very small value as soon as the distance (social distancing) between individuals is higher than $1.5 \mathrm{~m}$. From this point of view, government and health agencies have communicated largely. However, there was a misunderstanding of the real mode of transmission in this case, which has led to irrational measures such as organizing files in supermarket with obligation to use entrances different from the exit. But, although it has not been yet studied in the literature (to our knowledge), staying in the wake of an infector in a file for several minutes is certainly riskier than crossing the infector on a very short time. We recommend that, although social distancing must be encouraged as before, such measures directed against fast crossing should be removed since they are misleading for the public and could lead in fact to higher airborne transmission.

VIII.5. Immediate measures directed toward the way of life.

One of us made the prediction more than a year ago (Rowe et al., 2020a) that sub-Saharan Africa will not be stricken so much by the pandemic in the future due to airborne transmission considerations. Indeed, this low spreading of the disease has been observed up to now and a variety of explanations have been proposed (Adams et al., 2021; Wamai et al., 2021) . Rowe et al. (Rowe et al., 2021) have rationalized this observation considering an "outdoor" way of life in these countries. Outdoor way of life includes housing without air conditioning (AC) and large natural ventilation to ensure refreshment and open outdoor markets instead of supermarkets. Note that the African country which has been stricken the most by the disease is South Africa where the prevalence of AC is much higher. It has been observed (Engelbrecht et al., 2021) that in this country COVID-19 clusters have occurred there in closed supermarkets, most often equipped with $A C$.

Therefore, it can be thought that in many places of low latitude, like West Indies or Guyana, coming back as far as possible to the outdoor way of life could have immediate benefits. This necessitates waiving of $A C$ when possible and turning back to natural cooling, which implies large current of fresh air.

In many locations at high latitudes, heating cannot be avoided in winter, which implies indoor way of life, but as discussed in the previous section ventilation should be increased and outdoor activities (for example outdoor markets, sport activities) encouraged.

VIII. 6. Air monitoring (proxies).

As shown in sections VI and VII, for indoor situations the cheapest way to monitor the risk is a measurement of the increase of carbon dioxide concentration due to human respiration. However, too often, it has been stated that the concentration level alone is sufficient as a risk proxy and it has been proposed a limit around $800 \mathrm{ppm}$ (Health and Safety Executive, 2021) which could be considered as safe. We have shown throughout this present paper that communication on this limit is misleading as it ignores completely the question of the time of exposure. We propose the development of intelligent sensors that could provide several integrated values of carbon dioxide concentrations respectively for data acquired on different time intervals prior to data displaying. The time of exposure and mean concentration, as defined by equation (23), could be displayed by such sensors. 
medRxiv preprint doi: https://doi.org/10.1101/2022.01.13.22269234; this version posted January 17, 2022. The copyright holder for this preprint (which was not certified by peer review) is the author/funder, who has granted medRxiv a license to display the preprint in It is made available under a CC-BY-NC-ND 4.0 International license.

The present paper is mainly devoted to indoor situations. However, it has been recognized (Rowe et al., 2021) that in some special meteorological and topographical conditions the outdoor risk is non negligible in crowded areas. We suggest that an indicator of this kind of situations should be developed. On the short time, indicators of PM2.5 pollution could be used as they are closely correlated to this kind of conditions.

VIII.7. Auto-testing.

In the various formula that we have developed throughout the present paper in order to evaluate the risk, we have seen the importance of the proportion of infectors $r$. It must be understood that it impacts directly airborne transmission of the disease. From a statistical point of view, the value of the well-known incidence rate can be used to estimate $r$. However, it is clear that for small gathering ( $<50$ example of restaurants) the probability to have more than one infector is small $(<3 \%$ ) as long as the incidence rate is smaller than $0.06 \%$, as discussed in section VI.2. This value of the probability could be drastically reduced if, for some events, people will take the habit of auto-testing (and of course to give up the gathering when positive).

Auto testing is possible with rather cheap antigen tests that can be found in pharmacy. We suggest that strongly reducing this cost at a very low cost price affordable for the general population (with the government help if necessary). Information on when and how to use it, could lead to better results than a policy of sanitary pass that makes the implicit assumption that a vaccinated person cannot be an infector.

However it is clear that when the value of $r$ becomes too high such a policy will be very difficult to apply on a large scale.

VIII.8. Implications for interventions that are not targeting directly air quality

The most radical intervention to mitigate the spread of the pandemic has certainly been the various forms of lockdowns that, notably in western societies, constitute a major limitation to liberties and was unprecedented in non-war conditions. While the first lockdown might have been necessary, given the lack of governmental readiness to fight such pandemics in western societies, we now realize that, beyond the obvious socio-economic implications, it also has a significant downside related to psychological isolation and mental health. Given the above developments we should also consider the deleterious effects on people and families who live in small apartments and closed places where air is not adequately treated. Poorer families, children, women and people experiencing mental disorders have been particularly harmed by lockdowns (Ellis et al., 2021; Hao et al., 2020; lob et al., 2020), and this measure should be taken in only the most extreme circumstances. Moreover, the efficiency of lockdown strategies is a matter of debates (Chin et al., 2021; Bendavid et al., 2021) and from the present paper it is clear that gathering people that have not been tested in an indoor housing for a long time could be very counter-productive: it has been shown indeed that a large number of contaminations occur in family environment (Institut Pasteur, 2020; Madewell et al., 2021).

Far less radical, although very recent, contact-tracing apps on smartphones are the typical intervention that any digital policy would have considered to support health policy. Such apps were first introduced to help policy to fight the very lethal Ebola disease. However, their efficiency is dubious and their ethical character questionable. When air monitoring measures, discussed in previous sections, indicate a significant risk, the public should be informed in appropriate ways so 
medRxiv preprint doi: https://doi.org/10.1101/2022.01.13.22269234; this version posted January 17, 2022. The copyright holder for this preprint (which was not certified by peer review) is the author/funder, who has granted medRxiv a license to display the preprint in It is made available under a CC-BY-NC-ND 4.0 International license.

that behaviors can be adjusted. For risk induced by aerosol-based transmission, intuitive and responsive user interfaces could be developed to visualize outbreak risks in various room of buildings and alert facility managers and users in a way that could be similar and complement that outbreak risks related to fomite-based transmission (Li et al., 2021b). But mitigation measures such as contact tracing apps will have little effect against long range transmission by aerosols. These apps have not been designed to fight this transmission path of the pandemic and aerosol transmission was ignored at their inception. When aerosols are emitted from delta variant, it is the quantum concentrations (i.e. exhaled microdroplets in a way) in a given space that creates the major risk. Focusing on close crossing (less than one meter for more than 15 minutes as we did in France with stopCOVID) in a public space can be dangerous because people can feel safe (at least feel being well informed with their app), when in fact what they should be warned (possibly by their smartphone, but even better by public screens or specific systems) about the situation over air quality. However, given the airborne danger of delta variant, we consider that contact tracing apps are inappropriate for at least three reasons: First, to be effective they require that a very large share of the population uses them for contact tracing which has been considered unrealistic (Rowe, 2020) and is still the case. In fact, whereas contact tracing apps have been redesigned to be less intrusive (e.g Norway case) and their governmental communication to influence their adoption adapted in to be less coercive (e.g. France case), a common nudging tactic to influence their adoption has consisted in adding a number of features influencing individual benefits such as giving information about risky regions or allowing to show conformity to vaccination plans to access public places thus transforming a risk detection app into an information public health and a sanitary pass app. As a result, after vaccination campaigns, these apps have been hugely downloaded. However, the effective activation of the apps for personal risk detection is still very low. Second, as we emphasize in the present paper, relevant parameters, notably time of exposure to risk, and space, but not necessarily distance, to a likely infector, were not well understood by the project developers (Meijerink et al., 2021; Rowe et al., 2020b). Typically, distance for technology such as bluetooth is critical for accuracy and reliability (Meijerink et al., 2021), but if the risk is related to the nearly homogeneous spread of virus in a given space, the issue is about detecting the level of risk in this space and not necessarily identifying the smartphone of the closest infector. Third, such apps may both develop bad habits in the population and creates another danger for increasing potential discrimination and problems, if hacked (Rowe, 2020). In some countries such as Germany or Switzerland, fear of mass surveillance appears as the major hindrance towards app use. Conversely if major public spaces are equipped with air monitoring equipment currently monitoring $\mathrm{CO}_{2}$ as proxy - that display public information about air quality, contact tracing apps would not be needed. Such information would be permanently visible by the public on some fixed screens similar to clocks in such places. In addition, to increase their situational awareness (Bonaretti and Fischer-Pressler, 2021), those who are or feel potentially at risk could check the safety of places on their smartphones by accessing a public website where measures of all displays would be available on a map with color indicators. Both of these solutions would require people being proactive. As the situation may vary a lot from place to place or evolve rapidly, the population at risk could also use a warning emergency system conveying alerts through a dedicated device (Polenta et al., 2020) or some augmented reality app (Li et al., 2021b). Given our experimentation measures, such public displays would be highly trustworthy thanks to their high representational fidelity (notably current, nearly exact and relevant (on these notions see (Bonaretti and Fischer-Pressler, 2021))) of the $\mathrm{CO}_{2}$ measures and thus limit the use of such warning emergency systems to those at risk and not coerce all the population to acquiesce to a rampant form of data surveillance. The cost of such air monitoring equipment and public website will not be very high and they are a more ethical, relevant and scientifically valid choice given the prevalence of the aerosol transmission path than current digital policy based on smartphone close-contact tracing. 
medRxiv preprint doi: https://doi.org/10.1101/2022.01.13.22269234; this version posted January 17, 2022. The copyright holder for this preprint (which was not certified by peer review) is the author/funder, who has granted medRxiv a license to display the preprint in It is made available under a CC-BY-NC-ND 4.0 International license .

\section{Conclusion}

The present health policies in many countries suffer from an original sin which was the deny of airborne transmission. With the advent of new strains such as $\delta$ or $o$, which leads to a much higher viral load in respiratory fluids, it is clear that the spreading of the epidemic is now mainly airborne. However, the communication of most governments and health agencies are still mainly directed toward avoiding close contact and fomites transmission, although this last way is probably negligible. Even if the importance of ventilation and mask wearing is now acknowledged, the move toward strong decisions devoted to fight airborne transmission is still very timid. This is most regrettable since some mitigations measures in this field will not negatively impact people life, as it has been the case for others such as lockdown.

We feel that major implications for public health policies have not been drawn from the conclusion that new variants such as $\delta$ can increase dramatically airborne contamination. This is a significant conclusion of the present paper on which we draw attention to the health community. Following the approach of Wells (Riley et al., 1978; Wells, 1955) and of most recent researches ((Buonanno et al., 2020; Cortellessa et al., 2021) amongst others) we derive a variety of simple formulas allowing to estimate risks, either relative or absolute, in a variety of situations. They are applied to some specific observations of $\mathrm{CO}_{2}$ level in a variety of environments. We point out the importance of the time of exposure in risky situations.

The first major contribution of this paper is to highlight a number of interventions that need to be introduced, modified, or could be suppressed, as done in the previous section. We suggest that some measures can be immediately taken at very low cost, such as recommending using natural ventilation or natural cooling coupled to $\mathrm{CO}_{2}$ monitoring. In winter, slight opening of doors and windows, in countries where temperature or the mode of heating stays acceptable for this, could be used to bring back $\mathrm{CO}_{2}$ concentration to a satisfying level for the time of exposure considered. In hot countries avoiding AC to come back to natural cooling would also be good for reducing energy consumption.

We have shown, from the literature as well as from direct observation in real environments, that the ventilation systems, either natural or mechanical are often far from being satisfying from the pathogen air quality point of view. In the short term a large communication policy about ventilation checking should be promoted. Ventilation norms need to be revised to consider risk such as virus contamination. But in this case, the ventilation flow rate could be considered as the sum of the outdoor flow rate of fresh air and of the flow rate of air sterilizers able to sterilize large flows. Such apparatuses remain to be developed at a reasonable cost.

In the short term, even if these measures are costly, a first plan to implement them in places where public services are crucial such as hospitals and medical services (Polednik, 2021; Zhou and Ji, 2021), schools (Villanueva et al., 2021) and other public services is necessary (Eykelbosh, 2021). Notably it must be clearly communicated that risk is not only proportional to $\mathrm{CO}_{2}$ measures, but also to the probability that an infector is or has been in the room and to the time of exposure.

Finally, while digital means can certainly be of help, they should be directed at informing people (e.g. with appropriate screens or web applications possibly using augmented reality for particularly vulnerable persons, rather than digitally tracing their (social) behavior and surveilling them). With the introduction of smartphone-based contact-tracing apps further embedded in sanitary passes, the pandemic has considerably accelerated the pace of the transformation of western societies towards digital surveillance. While some initial intentions was hoped to be good, such trend is dangerous and shows that ethical use of the digital is still in its infancy. 
medRxiv preprint doi: https://doi.org/10.1101/2022.01.13.22269234; this version posted January $17,2022$. The copyright holder for this preprint (which was not certified by peer review) is the author/funder, who has granted medRxiv a license to display the preprint in It is made available under a CC-BY-NC-ND 4.0 International license .

We insist that thinking only in terms of social distancing or social interactions has become a paradigm that needs to be changed. Scientific literature demonstrates that we can be infected when we talk to each other, but other situations can be dangerous once we understand that the virus is airborne. As it can stay infectious in the air, we should not only consider the possibility of airborne infection in co-presence, typically when people face each other, but also when people follow each other in a file or even when infected people have left a room if this room is not correctly ventilated. These scenarios need to be highlighted in public information.

And last but not least, when the present pandemic will be over, what will stay in the mid and long term is the absolute necessity to change our mind and norms in matter of indoor air quality, in order to include this problem of airborne virus and pathogen transmission. This will be an enormous challenge for building technology. 
medRxiv preprint doi: https://doi.org/10.1101/2022.01.13.22269234; this version posted January $17,2022$. The copyright holder for this preprint (which was not certified by peer review) is the author/funder, who has granted medRxiv a license to display the preprint in It is made available under a CC-BY-NC-ND 4.0 International license .

\section{REFERENCES}

1. JHU, 2021. Coronavirus Resource Center. https://coronavirus. jhu. edu/map. html.

2. Carlin, G.L., Baumgartner, J.S., Moftakhar, T., Koenig, D., Negrin, L.L., 2021. Impact of COVID19 lockdown on suicide attempts A retrospective analysis of the springtime admissions to the trauma resuscitation room at the Medical University of Vienna from 2015-2020. Wiener Klinische Wochenschrift 133, 915-922.

3. Kuller, L.H., 2016. Epidemiology: Then and Now. Am. J. Epidem. 183, 372-380.

4. Randall, K., Ewing, E., Marr, L., Jimenez, J., Bourouiba, L., 2021. How did we get here: what are droplets and aerosols and how far do they go? A historical perspective on the transmission of respiratory infectious diseases. Interface Focus 11, 20210049.

5. Wells, W.F., 1955. Airborne Contagion and Air Hygiene. An Ecological Study of Droplet Infections. Harvard University Press, Cambridge, Massachussetts.

6. Riley, E.C., Murphy, G., Riley, R.L., 1978. Airborne Spread of Measles in A Suburban Elementary-School. Am. J. Epidem. 107, 421-432.

7. Rowe, B.R., Canosa, A., Drouffe, J.M., Mitchell, J.B.A., 2021. Simple quantitative assessment of the outdoor versus indoor airborne transmission of viruses and covid-19. Environ. Res. 198, 111189.

8. Rudnick, S.N., Milton, D.K., 2003. Risk of indoor airborne infection transmission estimated from carbon dioxide concentration. Indoor Air 13, 237-245.

9. Morawska, L., Cao, J., 2020. Airborne Transmission of SARS-CoV-2: The World Should Face the Reality. Environ. Int. 139, 105730.

10. New York Times, 2021. 239 experts with one big claim the coronavirus is airborne. https://www. nytimes. com/2020/07/04/health/239-experts-with-one-big-claim-thecoronavirus-is-airborne. $\mathrm{html}$.

11. Wang, C.C., Prather, K.A., Sznitman, J., Jimenez, J.L., Lakdawala, S.S., Tufekci, Z., Marr, L.C., 2021a. Airborne transmission of respiratory viruses. Science 373, eabd9149.

12. Greenhalgh, T., Jimenez, J.L., Prather, K.A., Tufekci, Z., Fisman, D., Schooley, R., 2021. Ten scientific reasons in support of airborne transmission of SARS-CoV-2. Lancet 397, 1603-1605.

13. Tang, J.W., Bahnfleth, W.P., Bluyssen, P.M., Buonanno, G., Jimenez, J.L., Kurnitski, J., Li, Y., Miller, S., Sekhar, C., Morawska, L., Marr, L.C., Melikov, A.K., Nazaroff, W.W., Nielsen, P.V., Tellier, R., Wargocki, P., Dancer, S.J., 2021. Dismantling myths on the airborne transmission of severe acute respiratory syndrome coronavirus-2 (SARS-CoV-2). Journal of Hospital Infection 110, 89-96.

14. CDC, 2021. SARS-CoV-2 Variant Classifications and Definitions. https://www. cdc. gov/coronavirus/2019-ncov/variants/variant-classifications. html. 
medRxiv preprint doi: https://doi.org/10.1101/2022.01.13.22269234; this version posted January 17,2022 . The copyright holder for this preprint (which was not certified by peer review) is the author/funder, who has granted medRxiv a license to display the preprint in It is made available under a CC-BY-NC-ND 4.0 International license .

15. WHO, 2021a. Tracking SARS-CoV-2 variants. https://www. who. int/en/activities/trackingSARS-CoV-2-variants/.

16. Li, B., Deng, A., Li, K., Hu, Y., Li, Z., Xiong, Q., Liu, Z., Guo, Q., Zou, L., Zhang, H., Zhang, M., Ouyang, F., Su, J., Su, W., Xu, J., Lin, H., Sun, J., Peng, J., Jiang, H., Zhou, P., Hu, T., Luo, M., Zhang, Y., 2021a. Viral infection and transmission in a large well-traced outbreak caused by the Delta SARS-CoV-2 variant. MedRxiv https://doi.org/10.1101/2021.07.07.21260122.

17. Teyssou, E., Delagreverie, H., Visseaux, B., Lambert-Niclot, S., Brichler, S., Ferre, V., Marot, S., Jary, A., Todesco, E., Schnuriger, A., Ghidaoui, E., Abdi, B., Akhavan, S., Houhou-Fidouh, N., Charpentier, C., Morand-Joubert, L., Boutolleau, D., Descamps, D., Calvez, V., Marcelin, A.G., Soulie, C., 2021. The Delta SARS-CoV-2 variant has a higher viral load than the Beta and the historical variants in nasopharyngeal samples from newly diagnosed COVID-19 patients. J. Infect. 83, E1-E3.

18. von Wintersdorff, C., Dingemans, J., van Alphen, L., Wolffs, P., van der Veer, B., Hoebe, C., Savelkoul, P., 2021. Infections caused by the Delta variant (B.1.617.2) of SARS-CoV-2 are associated with increased viral loads compared to infections with the Alpha variant (B.1.1.7) or non-Variants of Concern. Research Square https://www.researchsquare.com/article/rs$777577 / v 1$.

19. Vuorinen, V., Aarnio, M., Alava, M., Alopaeus, V., Atanasova, N., Auvinen, M., Balasubramanian, N., Bordbar, H., Erasto, P., Grande, R., Hayward, N., Hellsten, A., Hostikka, S., Hokkanen, J., Kaario, O., Karvinen, A., Kivisto, I., Korhonen, M., Kosonen, R., Kuusela, J., Lestinen, S., Laurila, E., Nieminen, H.J., Peltonen, P., Pokki, J., Puisto, A., Raback, P., Salmenjoki, H., Sironen, T., OOsterberg, M., 2020. Modelling aerosol transport and virus exposure with numerical simulations in relation to SARS-CoV-2 transmission by inhalation indoors. Saf. Sc. 130, 104866.

20. Johnson, G.R., Morawska, L., Ristovski, Z.D., Hargreaves, M., Mengersen, K., Chao, C.Y.H., Wan, M.P., Li, Y., Xie, X., Katoshevski, D., Corbett, S., 2011. Modality of human expired aerosol size distributions. J. Aerosol Sc. 42, 839-851.

21. Morawska, L., Johnson, G.R., Ristovski, Z.D., Hargreaves, M., Mengersen, K., Corbett, S., Chao, C.Y.H., Li, Y., Katoshevski, D., 2009. Size distribution and sites of origin of droplets expelled from the human respiratory tract during expiratory activities. Aerosol Sc. 40, $256-$ 269.

22. Brown, J.S., Gordon, T., Price, O., Asgharian, B., 2013. Thoracic and respirable particle definitions for human health risk assessment. Particle and Fibre Toxicology 10, 1-12.

23. Vejerano, E.P., Marr, L.C., 2018. Physico-chemical characteristics of evaporating respiratory fluid droplets. J. Roy. Soc. Interf. 15, 20170939.

24. Bustamante-Marin, X.M., Ostrowski, L.E., 2017. Cilia and Mucociliary Clearance. Cold Spring Harbor Perspectives in Biology 9, a028241.

25. Kuek, L.E., Lee, R.J., 2020. First contact: the role of respiratory cilia in host-pathogen interactions in the airways. American Journal of Physiology-Lung Cellular and Molecular Physiology 319, L603-L619. 
medRxiv preprint doi: https://doi.org/10.1101/2022.01.13.22269234; this version posted January 17,2022 . The copyright holder for this preprint (which was not certified by peer review) is the author/funder, who has granted medRxiv a license to display the preprint in It is made available under a CC-BY-NC-ND 4.0 International license .

26. German Federal Institute for Risk Assessment, 2021. Can the new type of coronavirus be transmitted via food and objects? https://www. bfr. bund. de/cm/349/can-the-new-type-ofcoronavirus-be-transmitted-via-food-and-objects. pdf.

27. Nurminen, M., Nurminen, T., Corvalan, C.F., 1999. Methodologic issues in epidemiologic risk assessment. Epidemiology 10, 585-593.

28. Hoffmann, M., Kleine-Weber, H., Schroeder, S., Krueger, N., Herrler, T., Erichsen, S., Schiergens, T.S., Herrler, G., Wu, N.H., Nitsche, A., Mueller, M.A., Drosten, C., Poehlmann, S., 2020. SARS-CoV-2 Cell Entry Depends on ACE2 and TMPRSS2 and Is Blocked by a Clinically Proven Protease Inhibitor. Cell 181, 271-280.

29. Hou, Y.J., Okuda, K., Edwards, C.E., Martinez, D.R., Asakura, T., Dinnon, K.H., Kato, T., Lee, R.E., Yount, B.L., Mascenik, T.M., Chen, G., Olivier, K.N., Ghio, A., Tse, L., V, Leist, S.R., Gralinski, L.E., Schafer, A., Dang, H., Gilmore, R., Nakano, S., Sun, L., Fulcher, M., LivraghiButrico, A., Nicely, N., I, Cameron, M., Cameron, C., Kelvin, D.J., de Silva, A., Margolis, D.M., Markmann, A., Bartelt, L., Zumwalt, R., Martinez, F.J., Salvatore, S.P., Borczuk, A., Tata, P.R., Sontake, V., Kimple, A., Jaspers, I., O'Neal, W.K., Randell, S.H., Boucher, R.C., Baric, R.S., 2020. SARS-CoV-2 Reverse Genetics Reveals a Variable Infection Gradient in the Respiratory Tract. Cell 182, 429-446.

30. Wu, J., Zha, P., 2020. Association of COVID-19 Disease Severity with Transmission Routes and Suggested Changes to Community Guidelines. preprint. org doi:10.20944/preprints202003.0246.v1.

31. Rockx, B., Kuiken, T., Herfst, S., Bestebroer, T., Lamers, M.M., Munnink, B.B., de Meulder, D., van Amerongen, G., van den Brand, J., Okba, N.M., Schipper, D., van Run, P., Leijten, L., Sikkema, R., Verschoor, E., Verstrepen, B., Bogers, W., Langermans, J., Drosten, C., van Vlissingen, M.F., Fouchier, R., de Swart, R., Koopmans, M., Haagmans, B.L., 2020. Comparative pathogenesis of COVID-19, MERS, and SARS in a nonhuman primate model. Science 368, 1012-1015.

32. Brouwer, A.F., Weir, M.H., Eisenberg, M.C., Meza, R., Eisenberg, J.N.S., 2017. Dose-response relationships for environmentally mediated infectious disease transmission models. Plos Computational Biology 13, e1005481.

33. Haas, C.N., Rose, J.B., Gerba, C.P., 2014. Quantitative Microbial Risk Assessment. John Wiley \& Sons, Inc., Hoboken, NJ.

34. Pan, M., Lednicky, J., Wu, C., 2019. Collection, particle sizing and detection of airborne viruses. Journal of Applied Microbiology 127, 1596-1611.

35. Yezli, S., Otter, J.A., 2011. Minimum Infective Dose of the Major Human Respiratory and Enteric Viruses Transmitted Through Food and the Environment. Food Environ. Virol. 3, 1-30.

36. Sze To, G.N., Chao, C.Y.H., 2010. Review and comparison between the Wells-Riley and doseresponse approaches to risk assessment of infectious respiratory diseases. Indoor Air 20, 216.

37. Haas, C.N., 1983. Estimation of Risk Due to Low-Doses of Microorganisms - A Comparison of Alternative Methodologies. Am. J. Epidem. 118, 573-582. 
medRxiv preprint doi: https://doi.org/10.1101/2022.01.13.22269234; this version posted January 17, 2022. The copyright holder for this preprint (which was not certified by peer review) is the author/funder, who has granted medRxiv a license to display the preprint in It is made available under a CC-BY-NC-ND 4.0 International license .

38. Louten, J., 2016. Virus Transmission and Epidemiology. In: Louten, J. (Ed.), Essential Human Virology. Academic Press, Elsevier Inc., pp. 71-92.

39. Teunis, P.F.M., Havelaar, A.H., 2000. The Beta Poisson dose-response model is not a singlehit model. Risk Analysis 20, 513-520.

40. Zwart, M.P., Hemerik, L., Cory, J.S., de Visser, J., Bianchi, F.J., Van Oers, M.M., Vlak, J.M., Hoekstra, R.F., Van der Werf, W., 2009. An experimental test of the independent action hypothesis in virus-insect pathosystems. Proceedings of the Royal Society B-Biological Sciences 276, 2233-2242.

41. Gammaitoni, L., Nucci, M.C., 1997. Using a mathematical model to evaluate the efficacy of TB control measures. Emerg. Infect. Dis. 3, 335-342.

42. Buonanno, G., Stabile, L., Morawska, L., 2020. Estimation of airborne viral emission: Quanta emission rate of SARS-CoV-2 for infection risk assessment. Environ. Int. 141, 105794.

43. Chen, C.C., Willeke, K., 1992. Aerosol Penetration Through Surgical Masks. American Journal of Infection Control 20, 177-184.

44. Weber, A., Willeke, K., Marchioni, R., Myojo, T., Mckay, R., Donnelly, J., Liebhaber, F., 1993. Aerosol Penetration and Leakage Characteristics of Masks Used in the Health-Care Industry. American Journal of Infection Control 21, 167-173.

45. Rengasamy, S., Eimer, B.C., Szalajda, J., 2014. A Quantitative Assessment of the Total Inward Leakage of $\mathrm{NaCl}$ Aerosol Representing Submicron-Size Bioaerosol Through N95 Filtering Facepiece Respirators and Surgical Masks. J. Occup. Environ. Hyg. 11, 388-396.

46. Bazant, M.Z., 2020. Video 5-2: Beyond the Well-Mixed Room-Natural Convection. MITOpenCourseWare https://ocw.mit.edu/resources/res-10-s95-physics-of-covid-19transmission-fall-2020/lecture-videos/video-5-2-beyond-the-well-mixed-room2014naturalconvection/.

47. Su, W., Yang, B., Melikov, A., Liang, C., Lu, Y., Wang, F., Li, A., Lin, Z., Li, X., Cao, G., Kosonen, R., 2022. Infection probability under different air distribution patterns. Build. Environ. 207, 108555.

48. Liu, H., He, S., Shen, L., Hong, J., 2021. Simulation-based study of COVID-19 outbreak associated with air-conditioning in a restaurant. PhFI 33, 023301.

49. Kwon, K.S., Park, J.I., Park, Y.J., Jung, D.M., Ryu, K.W., Lee, J.H., 2020. Evidence of LongDistance Droplet Transmission of SARS-CoV-2 by Direct Air Flow in a Restaurant in Korea. Journal of Korean Medical Science 35, e415.

50. Lu, J., Gu, J., Li, K., Xu, C., Su, W., Lai, Z., Zhou, D., Yu, C., Xu, B., Yang, Z., 2020. COVID-19 Outbreak Associated with Air Conditioning in Restaurant, Guangzhou, China, 2020. Emerg. Infect. Dis. 26, 1628-1631.

51. Toyokawa, T., Shimada, T., Hayamizu, T., Sekizuka, T., Zukeyama, Y., Yasuda, M., Nakamura, Y., Okano, S., Kudaka, J., Kakita, T., Kuroda, M., Nakasone, T., 2022. Transmission of SARSCoV-2 during a 2-h domestic flight to Okinawa, Japan, March 2020. Influenza and Other Respiratory Viruses 16, 63-71. 
medRxiv preprint doi: https://doi.org/10.1101/2022.01.13.22269234; this version posted January 17, 2022. The copyright holder for this preprint (which was not certified by peer review) is the author/funder, who has granted medRxiv a license to display the preprint in It is made available under a CC-BY-NC-ND 4.0 International license.

52. Chen, W., Zhang, N., Wei, J., Yen, H.L., Li, Y., 2020. Short-range airborne route dominates exposure of respiratory infection during close contact. Build. Environ. 176, 106859.

53. Cortellessa, G., Stabile, L., Arpino, F., Faleiros, D.E., Bos, W.V., Morawska, L., Buonanno, G., 2021. Close proximity risk assessment for SARS-CoV-2 infection. Sc. Tot. Environ. 794, 148749.

54. Cao, G., Awbi, H., Yao, R., Fan, Y., Siren, K., Kosonen, R., Zhang, J., 2014. A review of the performance of different ventilation and airflow distribution systems in buildings. Build. Environ. 73, 171-186.

55. ASHRAE, 2003. ANSI/ASHRAE Addendum $n$ to ANSI/ASHRAE Standard 62-2001 Ventilation for Acceptable Indoor Air Quality. https://www. ashrae. org/technical-resources/standards-andguidelines/standards-addenda/addenda-to-standard-62-2001.

56. ASHRAE, 2019. ANSI/ASHRAE Standard 62.1-2019 Ventilation for Acceptable Indoor Air Quality. https://www. ashrae. org/technical-resources/bookstore/standards-62-1-62-2.

57. JORF, 1978. Circulaire du 9 août 1978 modifiée relative à la révision du règlement sanitaire départemental (RSDT). https://www. legifrance. gouv. fr/jorf/id/JORFTEXT000000871642 7188-7222.

58. Déoux, S., 2010. Bâtir pour la santé des enfants. Medieco, Sciences \& Techniques.

59. CEN, 2019. EN 16798-1:2019, Part 1: Indoor Environmental Input Parameters for Design and Assessment of Energy Performance of Buildings Addressing Indoor Air Quality, Thermal Environment, Lighting and Acoustics. https://standards. iteh.

ai/catalog/standards/cen/b4f68755-2204-4796-854a-56643dfcfe89/en-16798-1-2019.

60. Morawska, L., Tang, J.L.W., Bahnfleth, W., Bluyssen, P.M., Boerstra, A., Buonanno, G., Cao, J.J., Dancer, S., Floto, A., Franchimon, F., Haworth, C., Hogeling, J., Isaxon, C., Jimenez, J.L., Kurnitski, J., Li, Y.G., Loomans, M., Marks, G., Marr, L.C., Mazzarella, L., Melikov, A.K., Miller, S., Milton, D.K., Nazaroff, W., Nielsen, P.V., Noakes, C., Peccia, J., Querol, X., Sekhar, C., Seppanen, O., Tanabe, S., Tellier, R., Tham, K.W., Wargocki, P., Wierzbicka, A., Yao, M.S., 2020. How can airborne transmission of COVID-19 indoors be minimised? Environ. Int. 142, 105832.

61. Morawska, L., Milton, D.K., 2020. It Is Time to Address Airborne Transmission of Coronavirus Disease 2019 (COVID-19). Clinic. Infect. Dis. 71, 2311-2313.

62. Setti, L., Passarini, F., De Gennaro, G., Barbieri, P., Perrone, M.G., Borelli, M., Palmisani, J., Di Gilio, A., Piscitelli, P., Miani, A., 2020. Airborne Transmission Route of COVID-19: Why 2 Meters/6 Feet of Inter-Personal Distance Could Not Be Enough. Int. J. Environ. Res. Pub. Health 17, 2932.

63. Zhang, R., Li, Y., Zhang, A.L., Wang, Y., Molina, M.J., 2020a. Identifying airborne transmission as the dominant route for the spread of COVID-19. Proceedings of the National Academy of Sciences of the United States of America 117, 14857-14863.

64. Wang, J.X., Cao, X., Chen, Y.P., 2021b. An air distribution optimization of hospital wards for minimizing cross-infection. Journal of Cleaner Production 279, 123431. 
medRxiv preprint doi: https://doi.org/10.1101/2022.01.13.22269234; this version posted January 17, 2022. The copyright holder for this preprint (which was not certified by peer review) is the author/funder, who has granted medRxiv a license to display the preprint in It is made available under a CC-BY-NC-ND 4.0 International license.

65. Khovalyg, D., Kazanci, O.B., Halvorsen, H., Gundlach, I., Bahnfleth, W.P., Toftum, J., Olesen, B.W., 2020. Critical review of standards for indoor thermal environment and air quality. Energy and Buildings 213, 109819.

66. Brussels: European Committee for Standardization, 2007. EN 13779:2007 Ventilation for Non-residential Buildings. Performance Requirements for Ventilation and Room-conditioning Systems. http://www. cres. gr/greenbuilding/PDF/prend/set4/WI_25_PreFV_version_prEN_13779_Ventilation_for_non-resitential_buildings. pdf.

67. Haut Conseil de la Santé Publique, 2021. Covid-19: aération, ventilation et mesure du $\mathrm{CO}_{2}$ dans les ERP. https://www. hcsp. fr/explore. cgi/avisrapportsdomaine?clefr=1009.

68. Wargocki, P., 2021. What we know and should know about ventilation. REHVA Journal 5-13.

69. JORF, 2012. Décret n 2012-14 du 5 janvier 2012 relatif à l'évaluation des moyens d'aération et à la mesure des polluants effectuées au titre de la surveillance de la qualité de l'air intérieur de certains établissements recevant du public. https://www. legifrance. gouv. fr/loda/id/JORFTEXT000025105291/2021-12-27/txt17.

70. Ribéron, J., Ramalho, O., Derbez, M., Berthineau, B., Wyart, G., Kirchner, S., Mandin, C., 2016. Air stuffiness index: from schools to dwellings. Pollution Atmosphérique 228, https://doi.org/10.4267/pollution-atmospherique.5466.

71. Canha, N., Mandin, C., Ramalho, O., Wyart, G., Riberon, J., Dassonville, C., Hanninen, O., Almeida, S., Derbez, M., 2016. Assessment of ventilation and indoor air pollutants in nursery and elementary schools in France. Indoor Air 26, 350-365.

72. Batiactu, 2018. La qualité de l'air intérieur des écoles françaises est-elle bonne ? https://www. batiactu. com/edito/qualite-air-interieur-ecoles-francaises-est-elle-bonne53396. php.

73. Fisk, W.J., 2017. The ventilation problem in schools: literature review. Indoor Air 27, 10391051.

74. Dassonville, C., Mandin, C., Ribéron, J., Wyart, G., Ramalho, O., Kirchner, S., 2013. Light indicator for indoor air stuffiness: experimental survey in 70 classrooms. Pollution Atmosphérique https://doi.org/10.4267/pollution-atmospherique.2098.

75. Ribéron, J., Ramalho, O., Mandin, C., Cochet, V. Guide d'application pour la surveillance du confinement de l'air dans les établissements d'enseignement, d'accueil de la petite enfance et d'accueil de loisirs. DESE/Santé N²012-086R, 1. 2012. CSTB, Département Energie Santé Environnement, Division Santé.

76. Sundell, J., Spengler, J., Wargocki, P., 2021. VENTILATION: WHY does no one take it seriously? Indoor Air 31, 605-607.

77. Somsen, G., van Rijn, C., Kooij, S., Bem, R.A., Bonn, D., 2020. Small droplet aerosols in poorly ventilated spaces and SARS-CoV-2 transmission. Lancet Respiratory Medicine 8, 658-659.

78. WHO, 2021b. Roadmap to improve and ensure good indoor ventilation in the context of COVID-19. https://www. who. int/publications/i/item/9789240021280. 
medRxiv preprint doi: https://doi.org/10.1101/2022.01.13.22269234; this version posted January 17, 2022. The copyright holder for this preprint (which was not certified by peer review) is the author/funder, who has granted medRxiv a license to display the preprint in It is made available under a CC-BY-NC-ND 4.0 International license .

79. Agence Régionale de la Santé - Bretagne, 1997. Règlement Sanitaire Départemental. https://www. bretagne. ars. sante. fr/sites/default/files/2016-12/rsd35_0. pdf.

80. Institut Pasteur, 2021. Modélisation COVID-19: Dynamique du variant Delta en France métropolitaine. https://modelisation-covid19. pasteur. fr/realtime-analysis/delta-variantdynamic/.

81. Hacisuleyman, E., Hale, C., Saito, Y., Blachere, N.E., Bergh, M., Conlon, E.G., SchaeferBabajew, D.J., DaSilva, J., Muecksch, F., Gaebler, C., Lifton, R., Nussenzweig, M.C., Hatziioannou, T., Bieniasz, P.D., Darnell, R.B., 2021. Vaccine Breakthrough Infections with SARS-CoV-2 Variants. N. Eng. J. Med. 384, 2212-2218.

82. Servellita, V., Sotomayor-González, A., Gliwa, A.S., Torres, E., Brazer, N., Zhou, A., Hernández, K.T., Sankaran, M., Wang, B., Wong, D., Wang, C., Zhang, Y., Reyes, K.R., Glasner, D., Deng, X., Streithorst, J., Miller, S., Frias, E., Rodgers, M., Cloherty, G., Hackett Jr., J., Philip, S., Topper, S., Sachdev, D., Chiu, C.Y., 2021. Predominance of antibody-resistant SARS-CoV-2 variants in vaccine breakthrough cases from the San Francisco Bay Area, California. MedRxiv https://doi.org/10.1101/2021.08.19.21262139.

83. Morawska, L., Allen, J., Bahnfleth, W., Bluyssen, P.M., Boerstra, A., Buonanno, G., Cao, J., Dancer, S.J., Floto, A., Franchimon, F., Greenhalgh, T., Haworth, C., Hogeling, J., Isaxon, C., Jimenez, J.L., Kurnitski, J., Li, Y., Loomans, M., Marks, G., Marr, L.C., Mazzarella, L., Melikov, A.K., Miller, S., Milton, D.K., Nazaroff, W., Nielsen, P.V., Noakes, C., Peccia, J., Prather, K., Querol, X., Sekhar, C., Seppanen, O., Tanabe, S.i., Tang, J.W., Tellier, R., Tham, K.W., Wargocki, P., Wierzbicka, A., Yao, M., 2021. A paradigm shift to combat indoor respiratory infection Building ventilation systems must get much better. Science 372, 689-691.

84. Leung, N.H., Chu, D.K., Shiu, E.Y., Chan, K.H., McDevitt, J.J., Hau, B.J., Yen, H.L., Li, Y., Ip, D.K., Peiris, J., Seto, W.H., Leung, G.M., Milton, D.K., Cowling, B.J., 2020. Respiratory virus shedding in exhaled breath and efficacy of face masks. Nature Medicine 26, 676-680.

85. Milton, D.K., Fabian, M., Cowling, B.J., Grantham, M.L., McDevitt, J.J., 2013. Influenza Virus Aerosols in Human Exhaled Breath: Particle Size, Culturability, and Effect of Surgical Masks. Plos Path. 9, e1003205.

86. Balazy, A., Toivola, M., Adhikari, A., Sivasubramani, S.K., Reponen, T., Grinshpun, S.A., 2006. Do $\mathrm{N} 95$ respirators provide $95 \%$ protection level against airborne viruses, and how adequate are surgical masks? American Journal of Infection Control 34, 51-57.

87. Albadra, D., Lo, S.N.G. The potential for natural ventilation as viable passive cooling strategy in hot developing countries. 30th International PLEA Conference 16-18 December 2014, CEPT University, Ahmedabad. 2014. 16-12-2014.

88. Kowalski, W.J., 2007. Air-Treatment Systems for Controlling Hospital-Acquired Infections. Heating, Piping and Air Conditioning Engineering 79, 2-22.

89. Ministère de la transition écologique, 2020a. Réglementation thermique RT2012. https://www. ecologie. gouv. fr/reglementation-thermique-rt2012.

90. French Ventilation Professionals, 2018. Le Livre blanc de la ventilation. https://www. batiment-ventilation. fr/fileadmin/A_PROPOS/Livre_Blanc_de_la_Ventilation__Acte_I_Mai_2018_v2.pdf. 
medRxiv preprint doi: https://doi.org/10.1101/2022.01.13.22269234; this version posted January 17, 2022. The copyright holder for this preprint (which was not certified by peer review) is the author/funder, who has granted medRxiv a license to display the preprint in It is made available under a CC-BY-NC-ND 4.0 International license.

91. Ministère de la transition écologique, 2020b. Réglementation environnementale RE2020. https://www. ecologie. gouv. fr/reglementation-environnementale-re2020.

92. Boverket - the Swedish National Board of Housing Building and Planning, 2021. The Swedish Obligatory Ventilation Control. https://www. boverket. se/en/start/building-insweden/swedish-market/laws-and-regulations/national-regulations/obligatory-ventilationcontrol/.

93. Ekberg, L., 2021. Inspection of ventilation systems. REHVA Journal 14-18.

94. Nielsen, P.V., 2009. Control of airborne infectious diseases in ventilated spaces. J. Roy. Soc. Interf. 6, S747-S755.

95. ICEB, 2014. Crèches: Réglementation Thermique aux dépens de la santé des enfants. https://www. asso-iceb. org/communique/creches-la-reglementation-thermique-auxdepens-de-la-sante-des-enfants/.

96. Casas, J., 2019. Integrity testing of HEPA filters: A practical approach. Cleanroom Technology: The International Journal of Contamination Control 41-43, https://www.cleanroomtechnology.com/news/article_page/Integrity_testing_of_HEPA_filter s_A_practical_approach/150453.

97. Lytle, C.D., Sagripanti, J.L., 2005. Predicted inactivation of viruses of relevance to biodefense by solar radiation. Journal of Virology $79,14244-14252$.

98. King, M., 2013. Calculating photolysis rates and estimating photolysis lifetimes. ECG Environmental Briefs 1, 1-2.

99. Zhang, N., Su, B., Chan, P.T., Miao, T., Wang, P., Li, Y., 2020b. Infection Spread and HighResolution Detection of Close Contact Behaviors. Int. J. Environ. Res. Pub. Health 17, 1445.

100. Rowe, B.R., Mitchell, J.B.A., Wathelet, M., Zekhini, N., 2020a. Transmission aéroportée du Covid-19 : « Il est temps d'agir avant le retour du froid ! ». https://www. lequotidiendumedecin. fr/actus-medicales/sante-publique/transmission-aeroportee-ducovid-19-il-est-temps-dagir-avant-le-retour-du-froid.

101. Adams, J., MacKenzie, M.J., Amegah, A.K., Ezeh, A., Gadanya, M.A., Omigbodun, A., Sarki, A.M., Thistle, P., Ziraba, A.K., Stranges, S., Silverman, M., 2021. The Conundrum of Low COVID-19 Mortality Burden in sub-Saharan Africa: Myth or Reality? COMMENT. Global Health-Science and Practice 9, 433-443.

102. Wamai, R.G., Hirsch, J.L., Van Damme, W., Alnwick, D., Bailey, R.C., Hodgins, S., Alam, U., Anyona, M., 2021. What Could Explain the Lower COVID-19 Burden in Africa despite Considerable Circulation of the SARS-CoV-2 Virus? Int. J. Environ. Res. Pub. Health 18, 8638.

103. Engelbrecht, S., Delaney, K., Kleinhans, B., Wilkinson, E., Tegally, H., Stander, T., van Zyl, G., Preiser, W., de Oliveira, T., 2021. Multiple Early Introductions of SARS-CoV-2 to Cape Town, South Africa. Viruses 13, 526.

104. Health and Safety Executive, 2021. Ventilation during the coronavirus (COVID-19) pandemic. https://www. hse. gov. uk/coronavirus/equipment-and-machinery/air-conditioning-andventilation/identifying-poorly-ventilated-areas. htm. 
medRxiv preprint doi: https://doi.org/10.1101/2022.01.13.22269234; this version posted January 17, 2022. The copyright holder for this preprint (which was not certified by peer review) is the author/funder, who has granted medRxiv a license to display the preprint in It is made available under a CC-BY-NC-ND 4.0 International license.

105. Ellis, A., Briggs, D., Lloyd, A., Telford, L., 2021. A ticking time bomb of future harm: Lockdown, child abuse and future violence. Abuse: An International Impact Journal 2, 37-48.

106. Hao, F., Tan, W., Jiang, L., Zhang, L., Zhao, X., Zou, Y., Hu, Y., Luo, X., Jiang, X., Mclntyre, R.S., Tran, B., Sun, J., Zhang, Z., Ho, R., Ho, C., Tam, W., 2020. Do psychiatric patients experience more psychiatric symptoms during COVID-19 pandemic and lockdown? A case-control study with service and research implications for immunopsychiatry. Brain Behavior and Immunity 87, 100-106.

107. lob, E., Steptoe, A., Fancourt, D., 2020. Abuse, self-harm and suicidal ideation in the UK during the COVID-19 pandemic. British Journal of Psychiatry 217, 543-546.

108. Chin, V., Ioannidis, J.P., Tanner, M.A., Cripps, S., 2021. Effect estimates of COVID-19 nonpharmaceutical interventions are non-robust and highly model-dependent. Journal of Clinical Epidemiology 136, 96-132.

109. Bendavid, E., Oh, C., Bhattacharya, J., loannidis, J.P., 2021. Assessing mandatory stay-athome and business closure effects on the spread of COVID-19. European Journal of Clinical Investigation 51, e13484.

110. Institut Pasteur, 2020. COVID-19 in primary schools: no significant transmission among children or from students to teachers. https://www. pasteur. fr/en/press-area/pressdocuments/covid-19-primary-schools-no-significant-transmission-among-children-studentsteachers.

111. Madewell, Z.J., Yang, Y., Longini, I.M., Halloran, M., Dean, N.E., 2021. Factors Associated With Household Transmission of SARS-CoV-2 An Updated Systematic Review and Meta-analysis. Jama Network Open 4, e2122240.

112. Li, S., Xu, Y., Cai, J., Hu, d., He, Q., 2021b. Integrated environment-occupant-pathogen information modeling to assess and communicate room-level outbreak risks of infectious diseases. Build. Environ. 187, 197394.

113. Rowe, F., 2020. Contact tracing apps and values dilemmas: A privacy paradox in a neoliberal world. International Journal of Information Management 55, 102178.

114. Meijerink, H., Mauroy, C., Johansen, M.K., Braaten, S.M., Lunde, C.U.S., Arnesen, T.M., Feruglio, S.L., Nygard, K., Madslien, E.H., 2021. The First GAEN-Based COVID-19 Contact Tracing App in Norway Identifies $80 \%$ of Close Contacts in "Real Life" Scenarios. Frontiers in digital health 3, 731098.

115. Rowe, F., Ngwenyama, O., Richet, J.L., 2020b. Contact-tracing apps and alienation in the age of COVID-19. Europ. J. Inform. Syst. 29, 545-562.

116. Bonaretti, D., Fischer-Pressler, D. Timeliness, Trustworthiness, and Situational Awareness: Three Design Goals for Warning with Emergency Apps. ICIS 2021 Proceedings.2. https://aisel.aisnet.org/icis2021/is_resilience/is_resilience/2. 2021. 12-12-2021.

117. Polenta, A., Rignanese, P., Sernani, P., Falcionelli, N., Mekuria, D.N., Tomassini, S., Dragoni, A.F., 2020. An Internet of Things Approach to Contact Tracing-The BubbleBox System. Information 11, 347. 
medRxiv preprint doi: https://doi.org/10.1101/2022.01.13.22269234; this version posted January $17,2022$. The copyright holder for this preprint (which was not certified by peer review) is the author/funder, who has granted medRxiv a license to display the preprint in It is made available under a CC-BY-NC-ND 4.0 International license.

118. Polednik, B., 2021. Exposure of staff to aerosols and bioaerosols in a dental office. Build. Environ. 187, 107388.

119. Zhou, Y., Ji, S., 2021. Experimental and numerical study on the transport of droplet aerosols generated by occupants in a fever clinic. Build. Environ. 187, 107402.

120. Villanueva, F., Notario, A., Cabanas, B., Martin, P., Salgado, S., Gabriel, M.F., 2021. Assessment of $\mathrm{CO} 2$ and aerosol (PM2.5, PM10, UFP) concentrations during the reopening of schools in the COVID-19 pandemic: The case of a metropolitan area in Central-Southern Spain. Environ. Res. 197, 111092.

121. Eykelbosh, A., 2021. Indoor $\mathrm{CO}_{2}$ sensors for COVID-19 risk mitigation: Current guidance and limitations. Vancouver, BC: National Collaborating Centre for Environmental Health https://ncceh.ca/documents/field-inquiry/indoor-co2-sensors-covid-19-risk-mitigationcurrent-guidance-and. 